\title{
The Nutritional Components of Beer and Its Relationship with Neurodegeneration and Alzheimer's Disease
}

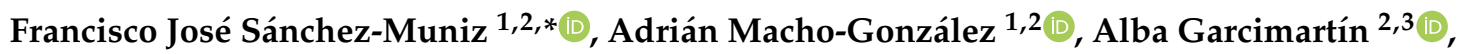 \\ Jorge Arturo Santos-López ${ }^{2,3} \mathbb{D}$, Juana Benedi ${ }^{2,3} \mathbb{D}$, Sara Bastida ${ }^{1,2} \mathbb{D}$ and \\ María José González-Muñoz ${ }^{2,4}$ (D) \\ 1 Departamento de Nutrición y Ciencia de los Alimentos, Facultad de Farmacia. Universidad Complutense de \\ Madrid, 28040 Madrid, Spain \\ 2 AFUSAN Research Group. Universidad Complutense de Madrid and Instituto de Investigación Sanitaria \\ from Hospital Clínico San Carlos (IdISSC), 28040 Madrid, Spain \\ 3 Departamento de Farmacología, Farmacognosia y Botánica, Facultad de Farmacia. Universidad \\ Complutense de Madrid, 28040 Madrid, Spain \\ 4 Departamento de Ciencias Biomédicas, Unidad Docente de Toxicología, Facultad de Farmacia, \\ Universidad de Alcalá, 28805 Alcalá de Henares, Spain \\ * Correspondence: frasan@ucm.es; Tel.: +34-913-941-828
}

Received: 10 June 2019; Accepted: 8 July 2019; Published: 10 July 2019

\begin{abstract}
The prevalence of degenerative diseases has risen in western countries. Growing evidence suggests that demenia and other cognition affectations are associated with ambient factors including specific nutrients, food ingredients or specific dietary patterns. Mediterranean diet adherence has been associated with various health benefits and decreased risk of many diseases, including neurodegenerative disorders. Beer, as part of this protective diet, contains compounds such as silicon and hops that could play a major role in preventing brain disorders. In this review, different topics regarding Mediterranean diet, beer and the consumption of their main compounds and their relation to neurological health have been addressed. Taking into account published results from our group and other studies, the hypothesis linking aluminum intoxication with dementia and/or Alzheimer's disease and the potential role of regular beer has also been considered. Beer, in spite of its alcohol content, may have some health benefits; nonetheless, its consumption is not adequate for all subjects. Thus, this review analyzed some promising results of non-alcoholic beer on several mechanisms engaged in neurodegeneration such as inflammation, oxidation, and cholinesterase activity, and their contribution to the behavioral modifications induced by aluminum intoxication. The review ends by giving conclusions and suggesting future topics of research related to moderate beer consumption and/or the consumption of its major compounds as a potential instrument for protecting against neurodegenerative disease progression and the need to develop nutrigenetic and nutrigenomic studies in aged people and animal models.
\end{abstract}

Keywords: beer; non-alcoholic beer; Mediterranean diet; aluminum; silicon; dementia; Alzheimer's disease; neuroprotection

\section{Introduction}

Increased lifespan in western countries has resulted in an impressively increased frequency of neurodegenerative diseases, the most common one being Alzheimer's disease [1]. According to WHO, it has been estimated that people with dementia in the world will reach 74.7 million in 2030 and 131.5 million in 2050 [2]. 
Neurovascular dysfunction, inflammatory processes, oxidative stress and mitochondrial dysfunction are critical factors in the pathogenesis and development of neurodegenerative diseases [3]. Alzheimer's disease has been pathologically characterized by neuronal degeneration, amyloidal plaques deposition, and neurofibrillary tangles in the brain of affected patients. The decrease in autophagy and the capacity to regulate brain-derived neurotrophic factor (BDNF) production have been reported, among others, as disease-emergent factors $[4,5]$. The neurodegeneration and hippocampal atrophy are even present at early phases of the disease [6].

While age and apolipoprotein E (APO-E) status represent nonmodifiable risk factors for this disease, diabetes, midlife hypertension, obesity, depression, smoking habits, cognitive inactivity, and low education are some of the known potentially modifiable factors [7]. Recently, the link between obesity and/or the metabolic syndrome with neurodegenerative diseases was proposed [8,9]. Along this line, Nuzzo et al. [10,11] evaluated how obesity and Alzheimer's disease markers are associated with inflammation, adipokine dyshomeostasis, oxidative stress, mitochondrial dysfunction, and neurodegeneration improvement in the frame of an insulin resistance model or in a functional ingredient-enriched high fat diet intervention,. Further, other factors such as chronodisruption [12], autophagy capacity [13], or mitochondriogenesis [14] have been proposed to influence cognitive disorders. In addition, some pathogens such as the Treponema and Borrela burgdorferi, and some viruses such as the type I herpes simplex (HSV-1), have been suggested to provoke chronical infections that have narrow links with the etiology of Alzheimer's disease. It has been reported that amyloid beta peptide $(A \beta)$ acts as an antimicrobial; thus, its accumulation would amplify the immune-response and the subsequent brain inflammation [15]. In addition, epigenetic factors, such as the exposition to some toxics, like lead and aluminum [16-18], have been proposed as a risk factor of dementia. It is well known that lead is a neuronal enhancer of oxidative stress, as it induces free radical accumulation and is able to modify the cellular patron of genome methylation [16].

Alzheimer's disease is characterized by a recurrent situation of cortical neuronal atrophy and destruction that mainly affect the parietal and temporal lobules, compromising three fundamental processes for the integral neuronal maintaining: (a) synapsis or interneuronal communication; (b) metabolism; and (c) reparation. The interruption of any of these processes means a cellular dysfunction that can culminate in apoptosis. Neuronal death provokes memory failure, personality changes, and other manifestations. The histopathological signs of Alzheimer's disease are neuritic plaques (composed of extracellular deposits of the $\mathrm{A} \beta$ protein) and neurofibrillary tangles (mainly composed of the tau protein) [19].

Several factors such as statins, light-to-moderate alcohol-consumption, Mediterranean diet-adherence, high educational attainment, physically and cognitively stimulating activities, and APO-E metabolism appear associated with a decreased risk of Alzheimer's disease onset. On the other hand, while APO-E remains the strongest predictor of Alzheimer's disease, aging, diabetes mellitus, smoking habits, and lower socioeconomical engagement, among others, are associated with increased risk of Alzheimer's development [20,21].

\section{Aluminum as an Alzheimer's Disease Risk Factor}

Aluminum is the most abundant metallic element in the Earth's crust and can be found in measurable quantities in food, soil, water, and air. The presence of aluminum in water contributes highly to daily aluminum consumption. Although this metal is normally found in trace amounts in the drinking water, the possibility for low-dose chronic exposure should not be discarded [22]. In addition, the widespread use of products made from, or containing, aluminum ensures the presence of this metal in our bodies.

Several years have passed since the first time that experts strongly claimed that human exposure to aluminum should be limited as it can exert deleterious effects even at small concentrations [23,24]. Nonetheless, it should be pointed out that the deleterious effects of aluminum in healthy individuals, 
though inevitable, will be low at normal exposure levels because of their low gastrointestinal uptake and bioavailability, and relatively high urinary excretion [25].

The hypothesis linking aluminum consumption and Alzheimer's disease, although highly controversial, has been supported by several epidemiological studies [26,27]. In addition, several studies in animal models have given light to this relationship. Therefore, experimental studies in rats and mice showed that aluminum accumulates in the brain cortex, hippocampus, and cerebellum [28], promoting the phosphorylation and aggregation of highly phosphorylated proteins, such as tau protein [29]. Other authors [17] have reported that the amygdala and the hippocampus are the brain areas with the highest aluminum content in an Alzheimer's disease model. In addition, Oshiro et al. [30] reported that aluminum accumulates more in glial cells than in neurons.

The brain has been found to be the target organ for aluminum accumulation; hence, this element can be primarily considered as a neurotoxic [31]. According to Kawahara [32], this metal induces in vivo as well as in vitro neuronal apoptosis. Aluminum may play an active role in the pathogenesis of critical neuropathologic lesions in Alzheimer's disease and other related disorders, through cross-linking hyperphosphorylated proteins [33,34]. In fact, Al-induced Alzheimer-like pathological changes were first attributed to tau proteins. Nevertheless, several biochemical, toxicological, cellular, and genetic studies have supported the "amyloid cascade hypothesis", which explains that the accumulation of A $\beta$ protein $(\mathrm{AP})$ and its neurotoxicity play a central role in the pathogenesis of Alzheimer's disease [35].

Walton [36] and Bolognin et al. [37] suggested that aluminum is engaged in the brain's neurofibrillary tangles formation by promoting the expression of the Amyloid precursor protein (APP) of the AP and increasing the levels of $\beta-40$ and $\beta-42$ fragments in the brain and should, therefore, be considered as a causative factor in Alzheimer's disease. In addition, aluminum appears to be associated with AP in the brain [38,39], as the chronic application of this metal caused the accumulation of AP in cultured neurons of rat cerebral cortex and in neuroblastoma cells. It is known that the monomeric form of AP has a random coiled structure, while the oligomeric AP have pleated sheet structures and form insoluble aggregates, named amyloid fibrils. The neurotoxicity of AP peptides has been studied in an aging model compared to freshly prepared AP in cultured neurons, and it has been demonstrated that the soluble oligomers are synaptotoxic and neurotoxic [35]. On the other hand, this metal can cause pro-oxidant activity. Exley [38] reported that this effect might be explained by the formation of an aluminum superoxide semireduced ion radical $\left(\mathrm{AlO}_{2}{ }^{2+}\right)$.

As is known, reactive oxygen species (ROS) interact with all biological macromolecules, including lipids, proteins, nucleic acids, and carbohydrates, contributing to neuronal death and, in turn, to the neuropathology associated with several diseases [28]. Although the exact mechanism by which the metal may influence disease processes remains unknown, an increase in oxidative stress and inflammatory events, two major causes of neurological diseases, have been proposed. Aluminum initiates and propagates an inflammatory response within the aging brain, suggesting that this may be one of the mechanisms by which the metals induce neurodegeneration [22]. In Alzheimer's disease transgenic mice models, dietary aluminum markedly increased lipid peroxidation and Aß-level presence [40]. In isolated systems, aluminum may increase the oxidative stress produced by transition metals such as iron [41] or copper [42]. In line with this observation, our group recently reported that aluminum intoxication contributes to a metal imbalance in the brain, which in turn would be responsible for this organ oxidation and reduced antioxidant capacity [43]. Our results are in line with those of several authors who described that $\mathrm{Al} 3+$ decreased the activity of the antioxidant enzymes catalase (CAT), superoxide dismutase (SOD), and glutathione peroxidase (GPx) [44,45]. Sharma et al. [46] found an increase of oxidative stress in the brain and serum with low reduced glutathione (GSH), GPx, CAT, and SOD levels after 10 weeks of aluminum chloride gavages exposure. Moumen et al. [47] reported increased concentrations of tiobarbituric acid reactive substances (TBARS) and glutathione S-transferase after aluminum intoxication. 
Other studies have demonstrated that aluminum intoxication increased brain TBARS levels and tumor necrosis factor alpha (TNF $\alpha$ ) expression, suggesting that oxidative stress and neuroinflammation was induced [48]. The induction of these processes has been proposed to be pathogenic for early events of Alzheimer's disease. Thus, brain TNF $\alpha$-rise has been shown to precede development of the disease in patients with mild cognitive impairment [49]. In line with the hypothesis that aluminum plays an active role in neurodegenerative diseases, Campbell [22] and Becaria et al. [50] found that brain TNF $\alpha$ expression was increased in mouse brains exposed to aluminum when compared to the control group. According to Lukiw et al. [51] aluminum exposure induced inflammatory gene expressions in primary neural cells.

Furthermore, aluminum exposure has been associated with the impairment of the cholinergic system by altering cholinergic projection function and structure, suggesting how this metal could contribute to the pathological process in neurodegenerative progression [52]. Martinez et al. [53] concluded that aluminum increased hippocampal reactive oxygen species and lipid peroxidation, reduced antioxidant capacity, and decreased acethylcholinesterase (AChE) activity.

It has been described that in Alzheimer's disease, AChE expression is substantially altered, and its activity is decreased in most brain regions. However, AChE activity is increased within and around the A $\beta$ plaques. Noremberg et al. [18] showed the contrary, that is, a decrease of the AChE activity in the presence of aluminum in the hippocampus and cortex, which would be a precursor of Alzheimer's disease. It is important to emphasize that since cerebral AChE is an important regulator of behavioral process, the decreased AChE activity found in the cortex and hippocampus may be an indicator of aluminum-induced damage in the brain. Kaizer et al. reported a decrease of AChE activity in the hypothalamus but verified an enhancement in the striatum area and no alterations in the hippocampus, cortex, and cerebellum [54]. These results demonstrate that aluminum acts differently depending on the dose and chemical form of $\mathrm{Al}^{3+}$ administration, the administration route (oral or intraperitoneal), and the time of exposure. Therefore, aluminum could produce a dose-dependent effect on AChE, stimulating $\mathrm{AChE}$ at low levels or short exposures and inhibiting $\mathrm{AChE}$ at high doses and/or long exposures periods. This polarized effect of aluminum on the AChE activity may be due to the direct effect of the metal or due to the peroxidation-induced changes in the structure of membrane following aluminum exposure [55].

Figure 1 shows a summary of the main deleterious effects of aluminum on brain cells. Although Oshiro et al. [30] reported that aluminum is highly accumulated on glial cells, the importance of those findings has been poorly discussed, and most studies have been centered on neurons' function. 


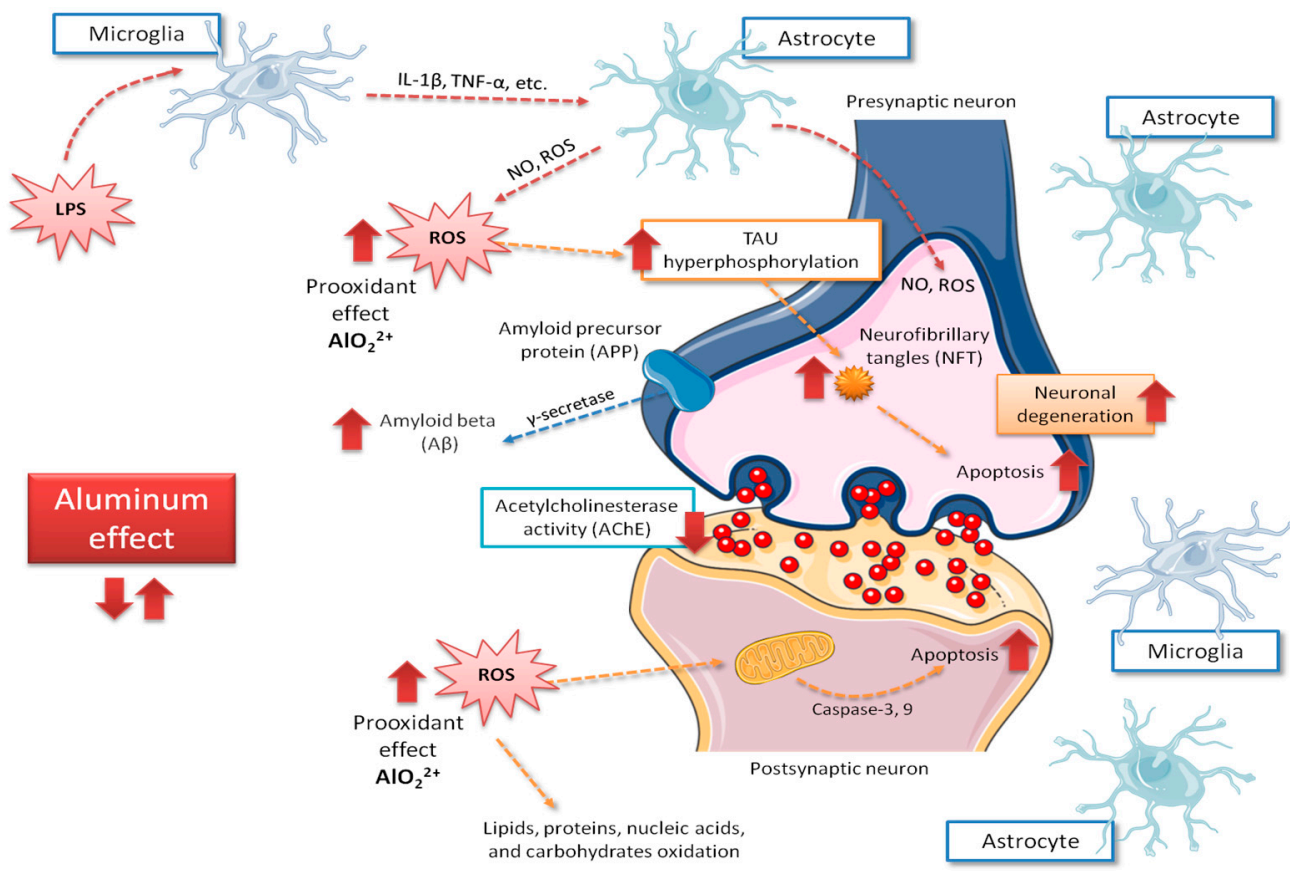

Figure 1. Main central aspects related to neurological mechanisms implicated in Alzheimer's disease caused by aluminum intoxication. Red arrows indicate the increase of the possible negative effects of aluminum exposure on the brain, those including ROS production increase and, in consequence, rise on tau phosphorylation, apoptosis, amyloid beta peptide $(\mathrm{A} \beta)$ accumulation and neurodegeneration. IL-1 $\beta$, interleukin 1-beta; LPS, lipopolysaccharide; NO, nitric oxide; ROS, reactive oxygen species; $\mathrm{TNF} \alpha$, tumor necrosis factor alpha.

\section{Nutritional Factors and Neurological Health-Beer as a Component of the Mediterranean Diet}

Cognition at various levels has been consistently associated with the nutritional status that in turn depends on the intake of specific nutrients or food ingredients [56], specific foods [57] or particular dietary patterns [58]. Among the most known factors, diet quality has been related to the hippocampus volume (the brain structure that is mainly associated with learning and memory) [59]. In elderly humans, the Mediterranean diet has been associated with reduced atrophy of the brain [60] and reduced amyloid peptides load [61]. In addition, the continuous stress induces the cortisol hormone to increase, a fact that can be a link between chronodisruption and the neurodegenerative disease as a consequence of distortion at neuronal renovation by cortisol at the paracortical gyrus $[62,63]$.

Based on large scientific evidence, the Mediterranean diet has been considered to be one of the healthiest diets [64-66] due to its high nutritional quality. In fact, when the level of adhesion to a Mediterranean diet model is optimal, there is a reduced risk of inadequate nutrient and bioactive compound intakes, or it has even been positively related with an increase in longevity [67-69]. The characteristics of this diet have been frequently summarized as a pyramid in which the frequency of food consumption is highlighted. Since their creation by Keys et al. [70], several modifications to the original pyramid have been proposed, trying to adapt the original one to present time or even considering the Mediterranean diet as an integral temple of life [71]. Thus, tridimensional pyramids [72], tables, and new figures [73] have appeared, showing some similarities to the original one, increasing the presence of new dietary compounds and dishes, and supplementary lifestyle information. It is well known Mediterranean diet is characterized by a high proportion of food of vegetable origin, where the presence of virgin olive oil is mandatory $[74,75]$. Fish, cheese, and yogurt are moderately consumed, while meat is rarely consumed alone and always forms part of complex dishes. Wine or beer during main meals is also one of its characteristics [76]. It is well known that the Mediterranean diet has been recognized to be an intangible heritage of humanity and due to its 
composition plurality, several authors $[77,78]$ justify the use of the term Mediterranean diets instead of Mediterranean diet.

Beer is one of the most consumed alcoholic beverages around the world. Table 1 shows data on beer consumption of most representative countries belonging to the different continents. The Czech Republic shows the highest per head consumption, with more than $150 \mathrm{~L}$ per year. There are other relevant beer consumers with more than $100 \mathrm{~L} /$ head/year. China is the highest consumer in the world, although its per habitant consumption is under $30 \mathrm{~L} /$ year [79].

Table 1. Beer consumption in different countries.

\begin{tabular}{ccc}
\hline Country & L Per Capita & Total National Consumption \\
\hline China & 29 & 43266 \\
United States & 74.8 & 24245 \\
Brazil & 60.4 & 12654 \\
Germany & 104.2 & 8412 \\
Russia & 58.60 & 8405 \\
Mexico & 65.1 & 7988 \\
Japan & 41.4 & 5251 \\
Spain & 84.8 & 3909 \\
Poland & 100.8 & 3892 \\
Canada & 57.7 & 2093 \\
Argentina & 49 & 1980 \\
Czech Republic & 143.3 & 1959 \\
Netherlands & 69.8 & 1186 \\
Austria & 106 & 928 \\
Belgium & 67.4 & 769
\end{tabular}

Per capita beer consumption by country of last data report by Kirin Holding Company at 2017 [79].

There is growing evidence from large-scale, population-based studies that long-term adherence to the MD may help to protect against dementia and preserve brain and cognitive function in the later stage of the lifespan [80-84]; however, negative-nonpositive information on the Mediterranean diet on this topic is also available [84-86].

According to the PREDIMED study, moderate beer-drinkers have a healthier lifestyle and display an overall dietary pattern closer to that of people following the traditional Mediterranean diet than their nondrinker counterparts (more cereals, legumes, vegetables, fish, and olive oil and fewer dairy products), although they also show a greater consumption of meat and meat products [87]. These authors also reported fewer cardiovascular disease risk factors among beer-drinkers that partially explain the protective role of beer in the development of atherosclerosis and cerebrovascular diseases.

Figure 2 shows some of the Mediterranean diet components from which a positive influence on cognitive health has been described. It has to be pointed out that the effect of the Mediterranean diet is due to its particular foodstuff component, and thus, it appears to be linked to its whole nutrient profile $[76,88,89]$, partially explaining the positive effects of a high Mediterranean diet adherence on brain health [90-94]. 


\section{Mediterranean Diet} compounds

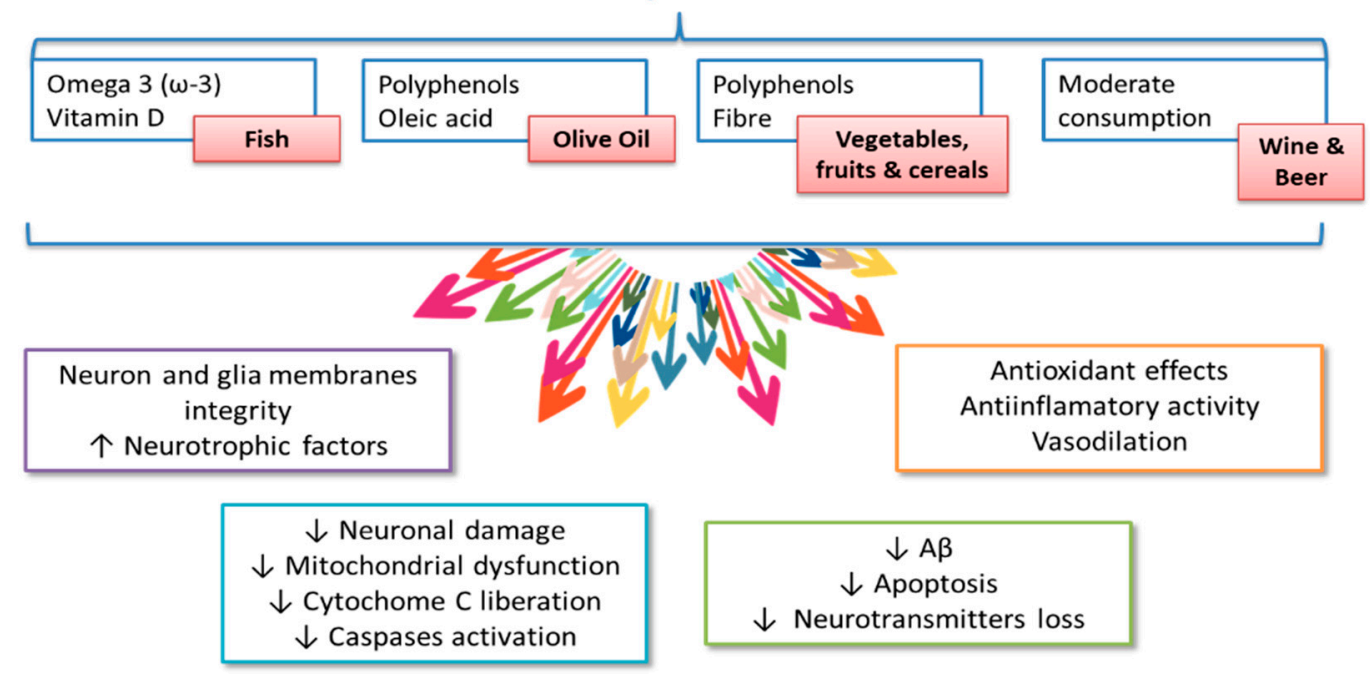

Figure 2. Components of the Mediterranean diet and potential mechanisms influencing cognitive health. Modified from El-Swefy and Atteia [20].

Some mechanisms have been proposed to explain the beneficial effects of the Mediterranean diet on mild cognitive impairment $[20,95,96]$ (summarized in Figure 3). Gardener et al. [96] found that Mediterranean diet adherence was associated with a reduced number of strokes and lower incidence in Alzheimer's disease and mild cognitive impairment development in elderly individuals. In addition, the Mediterranean diet may confer its favorable effects in cognitive function due to its antioxidant [97] and anti-inflammatory properties [98]. Oxidative stress has been largely associated with cognitive decline and neurodegenerative disorders [99], while inflammation has been linked to vascular health impairment, as well as brain damage, through amyloid peptide accumulation and subsequent activation of astrocytes and microglia [100]. Abuznait et al. [101] proposed that the Mediterranean diet induces an increase of neurotrophic factors related to neurotransmission, synaptic plasticity, and elimination of $A \beta$ from the brain. The positive Mediterranean diet effects on the pathogenesis of vascular disease and Alzheimer's disease have largely been linked to the reduction of oxidative stress, through the consumption of abundant antioxidant and anti-inflammatory agents (e.g., polyphenols) which, in turn, may alter the expression of inflammatory markers. Thus, supplemental foods such as extra virgin olive oil and nuts, particularly rich in phenolic compounds [102], may counteract oxidative processes in the brain by reducing, in turn, neurodegeneration. Other additional mechanisms attributed to polyphenols, such as cerebrovascular blood flow improvement, BDNF synthesis enhancement, neuronal signaling modulation, and neurogenesis stimulation should ameliorate neurologic health [103]. Nonetheless, the presence of other foods (such as fish rich in omega-3 polyunsaturated fatty acids) regularly found in the Mediterranean diet are also implicated in the reduced risk of cognitive decline and dementia of people showing high adherence to this diet. Light to moderate alcohol use may be associated with a reduced risk of incident dementia and Alzheimer's disease [104]. 




Figure 3. Main effects related to Mediterranean diet adherence on cognitive function. Green arrows indicate the increase of the possible effects on brain, those including ROS production decrease and, in consequence, less tau phosphorylation, apoptosis, $\mathrm{A} \beta$ accumulation, and neurodegeneration. IL-1 $\beta$, interleukin 1-beta; LPS, lipopolysaccharide; NO, nitric oxide; ROS, reactive oxygen species; $\mathrm{TNF} \alpha$, tumor necrosis factor alpha.

\section{Composition of Beer-Beneficial Aspects on Alzheimer's Disease}

Beer, a beverage probably originating in Mesopotamia with the Assyrians, Sumerians, and Babylonians (XXIV century B.C.), is one of the oldest recorded recipes. The brewing process was first documented on papyrus scrolls by ancient Egyptians [105]. Later, and due to barley crops being abundant, the brewing process extended to North Europe, being a safe alternative to drinking water. Monks were very much the foremost brewers of the Middle Age, with virtually every monastery having one brewery on site [106].

As is known, beer can be classified according to bottom or top fermentation yeast. Top-fermented beers include brown ale, mild ale, old ale, pale ale, stout, and wheat beer. The most commonly consumed types of beer in the world are pale lagers, which normally use a bottom-fermenting yeast. Main lagers include pale lager, bock, dunkel, helles, oktoberfestbier/märzen, pilsner, schwarzbier, and Vienna lager. In addition, there are non-alcoholic beers aimed at sectors of the population that do not want or cannot drink alcohol. The consumption of beer has grown during the last few decades, mostly among young adults. Currently, it is one of the most consumed beverages in the world, as shown in Table 1.

Composition can be different from one beer type to another; however, the average beer contains a not insignificant amount of nutrients, such as carbohydrates, protein/amino acids, minerals, vitamins, and other compounds, such as polyphenols (Tables 2 and 3) [76,88]. Among minerals, potassium, phosphorus, calcium, sodium, and silicon are the most abundant, while folic acid is the most abundant vitamin, which has even pushed nutritionists to consider this drink as a valuable source of folic acid, as a can of beer $(330 \mathrm{~mL})$ contains $20-25 \mu \mathrm{g}$ folate, an amount that covers $10 \%-15 \%$ and $5 \%-7 \%$ of the recommended intakes for this vitamin in men and women, respectively [107] (Table 2). In addition, 
beer has been considered a relevant source of some bioactive compounds with physiological properties (Table 3).

Table 2. Mean nutrient composition of regular beer.

\begin{tabular}{|c|c|c|}
\hline Nutrient & Units & Mean Content/100 g \\
\hline \multicolumn{3}{|l|}{ Proximates } \\
\hline Energy & Kcal & 91.97 \\
\hline Water & $\mathrm{g}$ & 43 \\
\hline Protein & $\mathrm{g}$ & 0.46 \\
\hline Total lipid (fat) & $\mathrm{g}$ & 0.0 \\
\hline Carbohydrate, by difference & $\mathrm{g}$ & 3.55 \\
\hline Fiber, total dietary & $\mathrm{g}$ & 0.0 \\
\hline \multicolumn{3}{|l|}{ Minerals } \\
\hline Calcium (Ca) & $\mathrm{mg}$ & 4 \\
\hline Cooper $(\mathrm{Cu})$ & $\mathrm{mg}$ & 0.01 \\
\hline Iron $(\mathrm{Fe})$ & $\mathrm{mg}$ & 0.02 \\
\hline Magnesium (Mg) & $\mathrm{mg}$ & 6 \\
\hline Manganese (Mn) & $\mathrm{mg}$ & 0.02 \\
\hline Silicon $(\mathrm{Si})$ & $\mathrm{mg}$ & 1.92 \\
\hline Selenium (Se) & $\mu \mathrm{g}$ & 0.6 \\
\hline Fluoride (F) & $\mu g$ & 44.2 \\
\hline Phosphorus (P) & $\mathrm{mg}$ & 14 \\
\hline Potassium $(\mathrm{K})$ & $\mathrm{mg}$ & 27 \\
\hline Sodium (Na) & $\mathrm{mg}$ & 4 \\
\hline Zinc (Zn) & $\mathrm{mg}$ & 0.01 \\
\hline \multicolumn{3}{|l|}{ Vitamins } \\
\hline Vitamin $C$, total ascorbic acid & $\mathrm{mg}$ & 0.0 \\
\hline Thiamin B1 & $\mathrm{mg}$ & 0.005 \\
\hline Riboflavin B2 & $\mathrm{mg}$ & 0.025 \\
\hline Niacin B3 & $\mathrm{mg}$ & 0.513 \\
\hline Pantothenic acid B5 & $\mathrm{mg}$ & 0.041 \\
\hline Vitamin B-6 & $\mathrm{mg}$ & 0.046 \\
\hline Folate, DFE & $\mu \mathrm{g}$ & 6 \\
\hline Choline, total & $\mathrm{mg}$ & 10.1 \\
\hline Cobalamine B12 & $\mu \mathrm{g}$ & 0.0 \\
\hline Vitamin A, RAE & $\mu \mathrm{g}$ & 0.0 \\
\hline Vitamin E ( $\alpha$-tocophenol) & $\mathrm{mg}$ & 0.0 \\
\hline Vitamin D & IU & 0.0 \\
\hline Vitamin K (phylloquinine) & $\mu \mathrm{g}$ & 0.0 \\
\hline \multicolumn{3}{|l|}{ Lipids } \\
\hline Saturated fatty acids & $\mathrm{g}$ & 0 \\
\hline Monounsaturated fatty acids & $\mathrm{g}$ & 0 \\
\hline Polyunsaturated fatty acids & $\mathrm{g}$ & 0 \\
\hline Cholesterol & $\mathrm{mg}$ & 0 \\
\hline \multicolumn{3}{|l|}{ Aminoacids } \\
\hline Alanine & $\mathrm{g}$ & 0.012 \\
\hline Aspartic acid & $\mathrm{g}$ & 0.016 \\
\hline Glutamic acid & $\mathrm{g}$ & 0.047 \\
\hline Glycine & $\mathrm{g}$ & 0.013 \\
\hline Proline & $\mathrm{g}$ & 0.035 \\
\hline Ethyl alcohol & $\mathrm{g}$ & $3.9 *$ \\
\hline
\end{tabular}

Mean content of each component/100 g beer. Proximate values include ales, lagers, porters, premium beers, and stouts. Other nutrients based on lager samples. Data from the National Nutrient Database for Standard Reference (USDA) [107]. * May vary according to the type of beer. 
Table 3. Phenolic compounds in beer

\begin{tabular}{|c|c|c|c|}
\hline \multicolumn{4}{|c|}{ Phenolic Compound $(\mathrm{g} / 100 \mathrm{~mL})$} \\
\hline Alkylmethoxyphenols & & 5-Caffeoylquinic acid & 0.08 \\
\hline 4-Vinylguaiachol & 0.15 & Caffeic acid & 0.03 \\
\hline Alkylphenols & & Ferulic acid & 0.26 \\
\hline 3-Methylcatechol & $1.00 \times 10^{-4}$ & Sinapic acid & 0.02 \\
\hline 4-Ethylcatechol & $6.00 \times 10^{-4}$ & Chalcones & \\
\hline 4-Vinyphenol & $4.53 \times 10^{-3}$ & Xanthohumol & $1.41 \times 10^{-3}$ \\
\hline Hydroxybenzaldehydes & & Flavanones & \\
\hline Vanillin & 0.02 & Isoxanthohumol & 0.04 \\
\hline Hydroxybenzoketones & & Naringin & $7.5 \times 10^{-4}$ \\
\hline 2,3-Dihydroxy-1-guaiacylpropanone & $3.4 \times 10^{-3}$ & 8-Prenylnaringenin & $1.04 \times 10^{-3}$ \\
\hline Hidroxycoumarins & & 6-Prenylnaringenin & $2.59 \times 10^{-3}$ \\
\hline Esculin & 0.02 & 6-Genarnylnaringenin & $4.29 \times 10^{-4}$ \\
\hline Umbelliferone & $1.67 \times 10^{-3}$ & Hydroxyphenylacetic acids & \\
\hline 4-Hidroxycoumarin & 0.11 & 4-Hydroxyphenilacetic acid & 0.03 \\
\hline Hidroxyphenylacetic acids & & Homovanillic acid & 0.05 \\
\hline 4-Hydroxyphenylacetic acid & 0.03 & Tyrosol & 0.32 \\
\hline Homovanillic acid & 0.05 & $(+)$-Catechin & 0.11 \\
\hline Benzoic acid derivatives & & (-)-Epicatechin & 0.06 \\
\hline Gallic acid 3-O-gallate & 0.3 & Procyanidin dimer B3 & 0.16 \\
\hline 2,6-Dihydroxybenzoic acid & 0.09 & Prodelphinidin trimer GCGCC & 0.04 \\
\hline 2-Hydroxybenzoic acid & 0.20 & Prodelphinidin trimer GCCC & $1.00 \times 10^{-2}$ \\
\hline 3-Hydroxybenzoic acid & 0.03 & Prodelphinidin trimer CGCC & 0.02 \\
\hline 3,5-Dihydroxybenzoic acid & 0.03 & Flavonols & \\
\hline Syringic acid & 0.02 & Quercetin (3-O-arabinoside) & $5.83 \times 10^{-4}$ \\
\hline Protocatechuic acid & 0.05 & Quercetin & $6.67 \times 10^{-3}$ \\
\hline Vanillic acid & 0.07 & 3,7-Dimetilquercitin & $2.50 \times 10^{-4}$ \\
\hline Gallic acid & 0.07 & Myricetin & $6.67 \times 10^{-4}$ \\
\hline Gentisic acid & 0.03 & Quercetin (3-O-rutinoside) & 0.09 \\
\hline Cinnamic acids & & Isoflavonoids & \\
\hline$p$-Coumaric acid & 0.10 & Daidzein & 0.005 \\
\hline$m$-Coumaric acid & 0.02 & Genistein & 0.01 \\
\hline$o$ - Coumaric acid & 0.15 & Biochanin A & 0.005 \\
\hline 4-Caffeoylquinic acid & 0.01 & Flavones & \\
\hline Other polyphenols & & Apigenin & $4.17 \times 10^{-3}$ \\
\hline Catechol & $1.10 \times 10^{-3}$ & $\alpha$-acids (humolones) & 0.17 \\
\hline Pyrogallol & $4.70 \times 10^{-3}$ & Iso- $\alpha$-acids (iso-humolones) & $0.06 \times 10^{-10}$ \\
\hline
\end{tabular}

Mean value in g/100 $\mathrm{mL}$ of beer. Modified from Arranz et al. [88].

Figure 4 shows the general chemical structure of most representative compounds found in beer. Among several components, beer contains the phenolic acids 4-hydroxyphenylacetic, vanillic, caffeic, syringic, p-coumaric, ferulic, and synaptic acids. Alkaline hydrolysis experiments show that most of the phenolic acids are present as bound forms, and only a small portion can be detected as free compounds [108]. 
<smiles>O=C(O)Cc1ccc(O)cc1</smiles><smiles>COc1cc(C(=O)O)ccc1O</smiles><smiles>COc1cc(C(=O)O)cc(OC)c1O</smiles><smiles>O=C(O)/C=C/c1ccc(O)c(O)c1</smiles><smiles>O=C(O)/C=C/c1ccc(O)cc1</smiles>

e)<smiles>COc1cc(/C=C/C(=O)O)ccc1O</smiles><smiles>COc1cc(/C=C/C(=O)O)cc(OC)c1O</smiles>

Figure 4. Chemical structure of the main phenolic acids found in beer. (a) 4-hydroxyphenylacetic acid; (b) vanillic acid; (c) syringic acid; (d) caffeic acid; (e) p-coumaric acid; (f) ferulic acid; and (g) sinapic acid [109].

Beer can also be an alcohol source, although its content is rather variable $(0 \%-15 \%$ Vol.) depending on the type, ingredients, and fermentation modality. Most available regular types of beer contain $4 \%-5 \%$ alcohol volumes equivalent to $3.2-4 \mathrm{~g}$ alcohol/100 $\mathrm{g}$ or $100 \mathrm{~mL}$. A non-alcoholic beer (also called beer without, beer low in alcohol or loose beer) is a beer with a very low or no alcohol content. Most non-alcoholic beers are lager, but there are also some ale varieties. There are four types of non-alcoholic beers: alcohol-free, dealcoholized, low-alcohol, and alcoholic beer. In the European Union, beer cannot contain more than $1 \%$ alcohol by volume to be labeled as "alcohol-free". In the UK, the legislation stipulates that beer can be labeled as non-alcohol or alcohol-free ('non-alcoholic') when its content does not exceed $0.05 \%$ by volume, as dealcoholized up to $0.5 \%$ and low-alcohol ('low in alcohol') up to $1.2 \%$. In the United States of America, beverages containing less than $0.5 \%$ alcohol by volume are considered non-alcoholic [109,110]. Every day, more and more non-alcoholic or low-in alcohol-beers are available and appreciated. Spain appears as the consumers' leader of non-alcoholic beer in Europe, with a 14\% rate of total beer consumption, almost triple that of its neighbor, France (INSERM) [110].

Several studies in both animals and humans on the potential brain's health benefits of regular beer consumption and of main representative compounds of beer have been realized and are referenced and detailed in Table 4.

Thus, the Helsinki Sudden Death Autopsy Series study, carried out in 125 males, concluded that beer consumption might protect against $A \beta$ aggregation in the brain [111]. The alcohol contained in the beer, apparently, can also exert a neuroprotective effect. This protection appears linked to signal transduction activation processes potentially involving ROS, several key protein kinases, and increased heat shock proteins [112]. In fact, significant reduced risks of cognitive loss or dementia in moderate, nonbinge consumers of wine, beer, and liquor have been observed. Downer et al. [113], using data from the Framingham Heart Study Offspring Cohort, found that alcohol consumption status in late life, but not in midlife, was associated with episodic memory and hippocampal volume. Compared to late life abstainers, moderate consumers had a larger hippocampal volume, while light consumers had higher episodic memory. 
Table 4. Main in vivo and in vitro studies of beer and its compounds' activity on neurodegenerative diseases.

\begin{tabular}{|c|c|c|c|c|}
\hline Compound & Species and Trial Mode & Formulation and Doses & Results & Reference \\
\hline Beer & $\begin{array}{c}\text { Clinical trial in humans with } 125 \\
\text { males of the Helsinki Sudden Death } \\
\text { autopsy }\end{array}$ & Total life consumption & $\begin{array}{l}\text { Neuroprotective effect by a possible } \\
\text { depletion of } A \beta \text { aggregation in brain }\end{array}$ & Kok et al. [111] \\
\hline Beer & $\begin{array}{l}\text { Cohort study with } 360 \text { patients in } \\
\text { early } A D \text {, biannually evaluation up to } \\
19-28 \text { years. }\end{array}$ & $\begin{array}{c}\text { Heavy drinkers ( } \geq 8 \text { alcoholic } \\
\text { drinks/week); mild-moderate drinkers } \\
\text { (1-7 alcoholic drinks/week); abstainers }\end{array}$ & $\begin{array}{l}\text { Increasing standard drinks of hard } \\
\text { liquor, but not beer or wine, was } \\
\text { associated with a faster rate of } \\
\text { cognitive decline, such as AD }\end{array}$ & Heymann et al. [114] \\
\hline Beer & $\begin{array}{l}\text { Cardiovascular Health Study, cohort } \\
\text { study with } 5888 \text { men and women } \\
\text { aged } \geq 65 \text { years and } 5-7 \text { years follow } \\
\text { up. }\end{array}$ & $\begin{array}{l}12 \mathrm{oz} \text { of beer with later magnetic } \\
\text { resonance imaging of the brain and } \\
\text { cognitive capacity evaluation. }\end{array}$ & $\begin{array}{l}\text { Limited beer consumption resulted in a } \\
\text { decreased risk of dementia or AD }\end{array}$ & Mukamal et al. [115] \\
\hline Beer & $\begin{array}{l}\text { Cohort study with } 980 \\
\text { community-dwelling individuals } \\
\text { aged } \geq 65 \text { years without dementia at } \\
\text { baseline, annually evaluation. }\end{array}$ & $\begin{array}{c}\text { Light drinkers ( } 1 \text { serving/month to } 6 \\
\text { servings/week); moderate drinkers (1-3 } \\
\text { servings/day); heavy drinkers ( } \geq 4 \\
\text { servings/day) }\end{array}$ & $\begin{array}{l}\text { Light to moderate alcohol intake was } \\
\text { associated with a lower risk of } \\
\text { dementia and AD, whereas intake of } \\
\text { beer and liquor was not associated with } \\
\text { incident dementia. }\end{array}$ & Luchsinger et al. [116] \\
\hline Beer & $\begin{array}{c}\text { Review of the observational studies, } \\
\text { trials, reviews, and meta-analyses in } \\
\text { humans }\end{array}$ & $\begin{array}{l}\text { Review from } 45 \text { reports since the early } \\
1990 \text { 's }\end{array}$ & $\begin{array}{l}\text { More than half of the papers indicate } \\
\text { that low consumption of beer reduced } \\
\text { the risk of dementia. While a minority } \\
\text { suggests the risk of neurodegeneration } \\
\text { due to its ethanol content }\end{array}$ & Collins et al. [112] \\
\hline Beer & $\begin{array}{l}\text { Immune response evaluation in } \\
\text { human peripheral blood } \\
\text { mononuclear cells with } 48-\mathrm{h} \\
\text { treatment }\end{array}$ & $\begin{array}{l}\text { Different beer types with } 2 \%-4 \%(v / v) \\
\text { ethanol }\end{array}$ & $\begin{array}{l}\text { Beer reduces the production of } \\
\text { neopterin and the tryptophan } \\
\text { degradation. Its immunosuppressive } \\
\text { capacity seems related to its } \\
\text { anti-inflammatory mechanisms. }\end{array}$ & Winkler et al. [117] \\
\hline Beer & In vitro experiments of pure samples & $\begin{array}{l}\text { Electron paramagnetic resonance } \\
\text { spectroscopy and antioxidant activity } \\
\text { of different types of beer }\end{array}$ & Beers exhibit antioxidant properties & Polak et al. [118] \\
\hline
\end{tabular}


Table 4. Cont.

\begin{tabular}{|c|c|c|c|c|}
\hline Compound & Species and Trial Mode & Formulation and Doses & Results & Reference \\
\hline Alcohol & $\begin{array}{l}\text { Review of the human, rodents and } \\
\text { cell culture neuroprotection } \\
\text { evaluations and epidemiological } \\
\text { studies }\end{array}$ & $\begin{array}{l}\text { Wine, beer, and liquor administration } \\
\text { and consumption }\end{array}$ & $\begin{array}{l}\text { Alcohol-dependent neuroprotected } \\
\text { state appears linked to an activation of } \\
\text { signal transduction processes of } \\
\text { reactive oxygen species. The alcohol } \\
\text { intake ameliorates inflammatory } \\
\text { pathways and increases hippocampal } \\
\text { acetylcholine release. Alcohol exposure } \\
\text { is inversely associated with dementia } \\
\text { through protective changes in cerebral } \\
\text { vasculature }\end{array}$ & Collins et al. [112] \\
\hline Beer/silicon & $\begin{array}{l}\text { Human intake with 6-h bioavailability } \\
\text { evaluation of silicon-enriched beer }\end{array}$ & $\begin{array}{l}0.6 \mathrm{~L} \text { beer containing } 22.5 \mathrm{mg} \mathrm{Si} \text { and } \\
4.6 \%(v / v) \text { ethanol }\end{array}$ & $\begin{array}{l}\text { Silicon in beer in monomeric form, is } \\
\text { readily bioavailable in healthy } \\
\text { volunteers }\end{array}$ & Sripanyakorn et al. [119] \\
\hline Beer/silicic acid & $\begin{array}{l}\text { Acute three-day study with male } \\
\text { NMRI mice }\end{array}$ & $\begin{array}{c}\text { Equivalent to moderate-high } \\
\text { consumption in humans (1 L/day; } 55 \mathrm{~g} \\
\text { alcohol/day). }\end{array}$ & $\begin{array}{l}\text { Beer, mainly associated with its silicon } \\
\text { content, reduces dietary aluminum } \\
\text { toxicokinetics and bioavailability } \\
\text { through a reduction of aluminum } \\
\text { uptake in the digestive tract and by } \\
\text { increasing its fecal excretion }\end{array}$ & Peña et al. [120] \\
\hline Beer/silicon & $\begin{array}{l}\text { Male NMRI mice on 3-month trial } \\
\text { with neuroprotective evaluation }\end{array}$ & $\begin{array}{l}2.5 \mathrm{~mL} \text { beer/per week }(5.5 \%(v / v)) \text {, and } \\
40 \mathrm{mg} \text { silicon/L/day }\end{array}$ & $\begin{array}{l}\text { Silicon appears to be effective in } \\
\text { preventing aluminum accumulation in } \\
\text { mouse's brain. Nonetheless, silicon } \\
\text { could act either as neuroprotector or } \\
\text { neurotoxic }\end{array}$ & Granero et al. [121] \\
\hline Beer/silicic acid & $\begin{array}{l}\text { Male NMRI mice on 3-month } \\
\text { evaluation }\end{array}$ & $\begin{array}{c}450 \mathrm{mg} \text { of aluminum nitrate, } 0.5 \mathrm{~mL} \\
\text { beer* }(5.5 \%(v / v)) / \text { day, and } 9 \mu \mathrm{g}^{\text {silicon/day }} \\
\text { *equivalent to moderate to high } \\
\text { consumption in humans (1 L/day) }\end{array}$ & $\begin{array}{l}\text { Beer consumption, and its content on } \\
\text { bioavailable silicon, reduces the } \\
\text { accumulation of aluminum in the body } \\
\text { and brain tissue, the lipid peroxidation, } \\
\text { and protected against the neurotoxic } \\
\text { effects through the regulation of } \\
\text { antioxidant enzymes }\end{array}$ & $\begin{array}{c}\text { González-Muñoz et al. } \\
{[48,122]}\end{array}$ \\
\hline
\end{tabular}


Table 4. Cont.

\begin{tabular}{|c|c|c|c|c|}
\hline Compound & Species and Trial Mode & Formulation and Doses & Results & Reference \\
\hline Beer/silicic acid & Male NMRI mice on 3-month trial & $\begin{array}{c}450 \mathrm{mg} \text { of aluminum nitrate, } 0.5 \mathrm{~mL} \\
\text { beer* }(5.5 \%(v / v)) / \text { day, and } 9 \mu \mathrm{g} \\
\text { silicon/day } \\
\text { *equivalent to moderate to high } \\
\text { consumption in humans ( } 1 \mathrm{~L} / \text { day) }\end{array}$ & $\begin{array}{l}\text { Silicic acid and beer block the metal } \\
\text { imbalance, inflammation, and } \\
\text { antioxidant defense impairment } \\
\text { induced by aluminum intoxication in } \\
\text { the brain }\end{array}$ & $\begin{array}{c}\text { González-Muñoz et al. } \\
\text { [43] }\end{array}$ \\
\hline $\begin{array}{l}\text { Non-alcoholic } \\
\text { beer/hops } \\
\text { extract/organic } \\
\text { silicon } \\
\text { (Silicium } \\
\text { organique G57' })\end{array}$ & $\begin{array}{l}\text { Male Wistar rats on 3-month trial } \\
\text { with behavioral, organs, and in vitro } \\
\text { studies of neurodegeneration }\end{array}$ & $\begin{array}{c}450 \mu \mathrm{g} \text { aluminum nitrate/kg/day; } 2 \mathrm{mg} \\
\text { hops extract/day; } 250 \mu \mathrm{g} \text { silicon/day; } 5 \\
\text { mL NA-beer/day* } \\
\text { *equivalent to moderate/high } \\
\text { consumption in humans (1 L/day) }\end{array}$ & $\begin{array}{l}\text { NA-beer, hops, and silicon ameliorated } \\
\text { behavioral modifications, blocked the } \\
\text { negative effect on the in vivo and } \\
\text { in vitro antioxidant status, and reduced } \\
\text { the inflammation markers in brain } \\
\text { induced by aluminum intoxication }\end{array}$ & Merino et al. [123] \\
\hline Hops extract & $\begin{array}{c}\text { Homozygous transgenic mice (V717F) } \\
\text { and heterozygous transgenic mice } \\
\text { (V717F/P267S) on a 2-, 6-, 11-, and } \\
\text { 18-month trial, and HEK293A cell } \\
\text { culture }\end{array}$ & $\begin{array}{l}\text { Hops extract added to drinking water } \\
\text { at a dose of } 2 \mathrm{~g} \text { extract } / \mathrm{L}\end{array}$ & $\begin{array}{l}\text { Hops extract reduced Alzheimer's } \\
\text { phenotypes in mice and prevented the } \\
\text { emotional disturbance at the } 18 \text { months } \\
\text { AD-mice. The extract significantly } \\
\text { reduced A } \beta \text { production in cultured } \\
\text { cells and presented } \gamma \text {-secretase } \\
\text { inhibitory activity }\end{array}$ & Sasaoka et al. [124] \\
\hline Hops pellets & $\begin{array}{l}\text { Hops pellets to obtain its chemical } \\
\text { characterization }\end{array}$ & $\begin{array}{l}\text { Chemical and quantitative } \\
\text { determination of hops compounds }\end{array}$ & $\begin{array}{l}\text { The presence of resveratrol in hops } \\
\text { highlights the potential } \\
\text { health-promoting effect of moderate } \\
\text { beer consumption }\end{array}$ & Callemien et al. [125] \\
\hline Silicon & $\begin{array}{l}\text { Human trial in } 7598 \text { women } \geq 75 \\
\text { years for evaluation of cognitive } \\
\text { function and neuroprotective effect }\end{array}$ & Silica content in drinking water & $\begin{array}{c}\text { Silicon in drinking water might reduce } \\
\text { the risk of } \mathrm{AD}\end{array}$ & $\begin{array}{l}\text { Gillette-Guyonnet et al. } \\
\text { [126] }\end{array}$ \\
\hline Silicon & $\begin{array}{l}\text { Review from human trials that } \\
\text { evaluate the neuroprotective effect of } \\
\text { silica in drinking water }\end{array}$ & $\begin{array}{l}\text { Reviews from tidies of silica in drinking } \\
\text { water }\end{array}$ & $\begin{array}{l}\text { Aluminum in water seems to have a } \\
\text { deleterious effect when the silica } \\
\text { concentrations were low, while the risk } \\
\text { of AD was reduced in subjects who had } \\
\text { higher daily silica intake }\end{array}$ & $\begin{array}{l}\text { Gillette-Guyonnet et al. } \\
\text { [127] }\end{array}$ \\
\hline
\end{tabular}


Table 4. Cont.

\begin{tabular}{|c|c|c|c|c|}
\hline Compound & Species and Trial Mode & Formulation and Doses & Results & Reference \\
\hline Silicon & Male Wistar rats on a 12-week trial & $\begin{array}{c}0.5 \mathrm{mg} \text { aluminum } / \mathrm{kg} / \text { day, and } 2 \mathrm{mg} \\
\text { silicon } / \mathrm{kg} / \text { day }\end{array}$ & $\begin{array}{l}\text { Silicon is considered an important } \\
\text { protector against lipid peroxidation } \\
\text { induced by aluminum intake }\end{array}$ & Noremberg et al. [18] \\
\hline Silicon & $\begin{array}{c}\text { SH-5HSY neuroblastoma cells line } \\
\text { with a } 24-\mathrm{h} \text { treatment }\end{array}$ & $\begin{array}{l}\text { Ladder concentration of } 50-250 \mathrm{ng} \\
\text { silicon/mL }\end{array}$ & $\begin{array}{c}\text { Silicon treatment reduced TBARS } \\
\text { levels, it also may act as neuroprotector } \\
\text { by inducing antiapoptotic effects at low } \\
\text { doses and may act as neurotoxic by } \\
\text { regulating necrosis and apoptosis } \\
\text { mechanisms at high doses. }\end{array}$ & Garcimartín et al. [128] \\
\hline Beer/melatonin & $\begin{array}{c}\text { Human trial with healthy volunteers } \\
\text { (4 men and } 3 \text { women) aged } 20 \text { to } 30 \\
\text { years. }\end{array}$ & $\begin{array}{l}\text { Different beer brands with diverse } \\
\text { ethanol content }\end{array}$ & $\begin{array}{l}\text { Melatonin contained in beer showed } \\
\text { antioxidant, oncostatic, and immune } \\
\text { enhancer activities }\end{array}$ & Maldonado et al. [129] \\
\hline Melatonin & $\begin{array}{c}\text { Review of the main effects on AD } \\
\text { pathology }\end{array}$ & $\begin{array}{l}\text { Main research publications on the } \\
\text { melatonin pathological mechanisms } \\
\text { related to AD through different } \\
\text { approaches }\end{array}$ & $\begin{array}{l}\text { Prevention of amyloid overproduction, } \\
\text { reduction of tau phosphorylation, } \\
\text { antioxidant ability, modulates } \\
\text { inflammation, anticholinesterase agent, } \\
\text { prevents mitochondrial damage and } \\
\text { apoptosis. }\end{array}$ & $\begin{array}{l}\text { Rosales-Corral et al. } \\
\text { [130] }\end{array}$ \\
\hline Melatonin & $\begin{array}{c}\text { Transgenic mice Tg2576 on an 8-, 9.5-, } \\
\text { 11-, and 15.5-month survival study } \\
\text { trial to evaluate neuroprotective effect }\end{array}$ & $\begin{array}{l}0.5 \mathrm{mg} / \mathrm{mL} \text { melatonin administration to } \\
\text { obtain A } \beta \text { measurements in brain, } \\
\text { quantitative immunoblots of APP } \\
\text { levels, and nitrotyrosine measurements }\end{array}$ & $\begin{array}{l}\text { The melatonin administration proved a } \\
\text { reduction of major AD markers and } \\
\text { brain } A \beta \text { levels }\end{array}$ & Matsubara et al. [131] \\
\hline Melatonin & $\begin{array}{c}\text { Male swiss albino mice in a 5-day } \\
\text { neuroprotective effect evaluation } \\
\text { experiment }\end{array}$ & $\begin{array}{c}50 \mathrm{mg} \text { melatonin } / \mathrm{kg} \text { body weight and } \\
5 \mu \mathrm{A} A \beta_{42-1} \text { intracerebroventricularly } \\
\text { administrated }\end{array}$ & $\begin{array}{l}\text { The treatment reduced A } \beta \text {-induced } \\
\text { oxidative stress, related to ROS and } \\
\text { proinflammatory cytokines IL6 and } \\
\text { IL1- } \beta \text {, and the intracellular calcium } \\
\text { levels and acetylcholinesterase activity } \\
\text { in the neocortex and hippocampus } \\
\text { regions }\end{array}$ & Masilamoni et al. [132] \\
\hline
\end{tabular}


Table 4. Cont.

\begin{tabular}{|c|c|c|c|c|}
\hline Compound & Species and Trial Mode & Formulation and Doses & Results & Reference \\
\hline Melatonin & $\begin{array}{c}\text { Review of the in vivo and in vitro } \\
\text { studies }\end{array}$ & $\begin{array}{l}\text { Reviews about the effects on the } \\
\text { prevention of neurodegenerative } \\
\text { diseases and their molecular } \\
\text { mechanism }\end{array}$ & $\begin{array}{l}\text { Melatonin is significantly decreased in } \\
\text { elderly AD individuals and associated } \\
\text { with the emergence of } \mathrm{AD} \text {, it exhibits a } \\
\text { protective effect on the cholinergic } \\
\text { system and protects brain neurons from } \\
\text { damage and death by increasing } \\
\text { viability in hippocampal neurons and } \\
\text { glial cells }\end{array}$ & $\begin{array}{l}\text { Hornedo-Ortega et al. } \\
\text { [133] }\end{array}$ \\
\hline $\begin{array}{l}\text { Phenolic } \\
\text { compounds from } \\
\text { beer }\end{array}$ & $\begin{array}{l}\text { In vitro anti-AChE and anti-BChE } \\
\text { activities of simple phenolic acids }\end{array}$ & $\begin{array}{c}\text { Phenolic solutions at their beer } \\
\text { concentration. IC50 values at } 336 \text { and } \\
160 \mathrm{mM} \text { calculated for AChE and BChE, } \\
\text { respectively }\end{array}$ & $\begin{array}{l}\text { Phenolic acids from beer can play a role } \\
\text { in neuroprotection by through an } \\
\text { inhibition of cholinesterases }\end{array}$ & Szwajgier [134] \\
\hline $\begin{array}{l}\text { Phenolic } \\
\text { compounds from } \\
\text { malt }\end{array}$ & $\begin{array}{l}\text { In vitro studies of the phenolic } \\
\text { fraction profile from several malt } \\
\text { types. }\end{array}$ & $\begin{array}{l}\text { Phenolic solution at different } \\
\text { concentrations to inhibit } \mathrm{AChE} \text { and } \\
\text { BChE enzymes }(\sim 0.38-1 \mathrm{mM} / \mathrm{L})\end{array}$ & $\begin{array}{l}\text { The main phenolic compounds from } \\
\text { malt (ferulic acid, p-coumaric, } \\
\text { 4-hydroxybenzoic, and sinapic acids). } \\
\text { Among them, the ferulic and } \\
\text { p-coumaric acids showed a high } \\
\text { neuroprotective role and can be } \\
\text { considered as possible anti-AD agents }\end{array}$ & $\begin{array}{c}\text { Szwajgier and Borowiec } \\
\text { [135] }\end{array}$ \\
\hline $\begin{array}{l}\text { Phenolic } \\
\text { compounds from } \\
\text { beer }\end{array}$ & $\begin{array}{l}\text { Female Tg2576 mice on a } 14 \text { months } \\
\text { trial to evaluate the pathology of AD }\end{array}$ & $\begin{array}{l}\text { Different diets including } 0.5 \% \text { phenolic } \\
\text { compounds evaluated through } \\
\text { immunohistochemistry and } \\
\text { morphometry of } \mathrm{A} \beta \text { deposits }\end{array}$ & $\begin{array}{l}\text { The extracted phenolic compounds } \\
\text { prevent } A D \text { pathology development } \\
\text { through the regulation of } A \beta \\
\text { aggregation pathway }\end{array}$ & Hamaguchi et al. [136] \\
\hline Xanthohumol & $\begin{array}{c}\text { Wild-type murine neuroblastoma } \\
\text { Neuro2a cells (N2a/WT) and N2a } \\
\text { stably transfected with human APP } \\
\text { Swedish mutant (N2a/APP) on a 24-h } \\
\text { treatment }\end{array}$ & $\begin{array}{l}0-25 \mu \mathrm{M} \text { Xanthohumol in cell culture } \\
\text { and later comparative proteomics, } \\
\text { immunocytochemistry of } A \beta_{1-40} \text { and } \\
\qquad A \beta_{1-42}\end{array}$ & $\begin{array}{c}\text { Xanthohumol suppresses A } \beta \\
\text { production and tau } \\
\text { hyperphosphorylation via APP } \\
\text { processing and the GSK- } 3 \beta \text { pathway. } \\
\text { Thus, it may have potential effects for } \\
\text { the treatment of AD }\end{array}$ & Huang et al. [137] \\
\hline Iso- $\alpha$-acids & $\begin{array}{l}\text { Alzheimer's model in 5xFAD mice on } \\
\text { a three-month period to evaluate } \\
\text { cognitive function in the progression } \\
\text { of dementia }\end{array}$ & $0.05 \%(w / w)$ of the iso- $\alpha$-acids & $\begin{array}{l}\text { The iso- } \alpha \text {-acids suppressed the } \\
\text { neuroinflammation markers IL- } 1 \beta \text { and } \\
\text { chemokine, and improve cognitive } \\
\text { function }\end{array}$ & Ano et al. [138] \\
\hline
\end{tabular}


Table 4. Cont.

\begin{tabular}{|c|c|c|c|c|}
\hline Compound & Species and Trial Mode & Formulation and Doses & Results & Reference \\
\hline Iso- $\alpha$-acids & $\begin{array}{c}\text { Male Crl:CD1(ICR) mice, } \\
\text { vagotomized male ICR mice, and } \\
\text { Sprague-Dawley (SD) rats on a } \\
\text { 3-month period to evaluate cognitive } \\
\text { function test, especially } \\
\text { hippocampus-dependent memory }\end{array}$ & $1 \mathrm{mg} / \mathrm{kg}$ iso- $\alpha$-acids & $\begin{array}{l}\text { Iso- } \alpha \text {-acids activate dopamine D1 } \\
\text { receptor-signaling in the hippocampus } \\
\text { and improves spatial and object } \\
\text { recognition memory functions }\end{array}$ & Ano et al. $[139,140]$ \\
\hline Iso- $\alpha$-acids & $\begin{array}{l}\text { Male C57BL/6J mice treated for } 3 \\
\text { months }\end{array}$ & $\begin{array}{c}\text { Dietary intake of } 0.05 \%(w / w) \\
\text { iso- } \alpha \text {-acids to evaluate episodic and } \\
\text { spatial memory and microglia analysis }\end{array}$ & $\begin{array}{l}\text { Reduced inflammation in the brain and } \\
\text { prevent the cognitive impairment } \\
\text { associated with normal aging }\end{array}$ & Ano et al. [140] \\
\hline Iso- $\alpha$-acids & $\begin{array}{l}\text { Male C57BL/6J mice on an AD model } \\
\text { (5xFAD transgenic) on a } 7 \text {-day trial }\end{array}$ & $\begin{array}{l}1 \mathrm{mg} / \mathrm{kg} \text { iso- } \alpha \text {-acids and later } \\
\text { transcriptome analysis }\end{array}$ & $\begin{array}{l}\text { Reduced } \mathrm{A} \beta \text { in the brain and increased } \\
\text { the expression of transthyretin in the } \\
\text { hippocampus, thus displayed } \\
\text { protective effects AD pathologies }\end{array}$ & Fukuda et al. [141] \\
\hline $\begin{array}{l}\text { Beer/iso- } \alpha \text {-acids } \\
\text { from hops extract }\end{array}$ & $\begin{array}{l}\text { Male C57BL/6J mice on a long-term } \\
\text { cognitive evaluation trial }\end{array}$ & $\begin{array}{l}1 \mathrm{mg} \text { extract } / \mathrm{kg} \text { equivalent to } 4.8 \\
\mathrm{mg} / \text { day in humans ( } 60 \mathrm{~kg} \text { body weight) } \\
\text { or } 0.17-0.3 \mathrm{~L} / \text { day of beers }\end{array}$ & $\begin{array}{l}\text { Iso- } \alpha \text {-acids could improve working } \\
\text { memory in dementia and } \\
\text { visual/reversal discrimination learning, } \\
\text { which are considered high-order } \\
\text { cognitive functions. }\end{array}$ & Ayabe et al. [142] \\
\hline
\end{tabular}

reactive oxygen species; $\mathrm{Si}$, silicon; $\mathrm{TNF} \alpha$, tumor necrosis factor alpha. 
Hops and silicon are two of the most important components of beer, and their composition and effects are briefly described in the following subsections.

\subsection{Hops (Humulus lupulus L.)}

Hops, one of the raw materials of beer, brings bitterness and serves as an important source of phenolic compounds. Polyphenols, mainly catechins, flavonoids, phenolic acids, prenylated chalcones, and proantocianidins, comprise about $14.4 \%$ of dried hops cones [143]. Around one fourth of polyphenols in beer originates from hops, and the rest belongs to malt [144]. Moreover, hops provide a resin containing monoacyl phloroglucinols that are precursors of bitter acids (e.g., $\alpha$-acid humulones and iso- $\alpha$-acids) during beer production. Simple phenols, benzoic acid derivatives and cinnamic acid, coumarins, catechins, di- and tri-oligomeric proanthocyanidins, prenylated chalcones, and $\alpha-$ and iso- $\alpha$-acids derived from hops are different classes of polyphenols in beer (Table 3 and Figure 4 ). Hops and most common regular beers contain 8-prenylnaringenin, which is a potent phytoestrogen [145]. Hops also contain myrcene, humulene, xanthohumol, isoxanthohumol, myrcenol, linalool, tannins, and resin, as well as 2-metilbutan-2-ol, which is a component of hops brewing [146]. Arranz et al. [76] reported that these beer compounds show different in vitro biological activities, such as antioxidant, anticarcinogenic, anti-inflammatory, estrogenic, and antiviral. According to Ano et al. [138] the iso- $\alpha$-acids contained in beer may be useful for the prevention of dementia due to their ability to suppress neuroinflammation and improve cognitive function. These authors demonstrated that the consumption of iso- $\alpha$-acids, the hops-derived bitter compounds in beer, prevents inflammation and Alzheimer's disease pathology in a mice model, via the regulation of microglia activation, and therefore prevents the inflammation-related brain disorders [140]. The iso- $\alpha$-acids, as agonists of peroxisome proliferator-activated receptor gamma (PPAR- $\gamma$ ), increase microglia phagocytosis of A $\beta$ and suppress inflammation in neuronal tissue [147]. Xanthohumol has been defined as a very important compound of hops and beer due to its positive effects as an antioxidant and neuroprotective described in some central papers [148]. In this line, Huang et al. [137] found several metabolic pathways where prenylflavonoid xantuhumol can be engaged as protective in some neurodegenerative diseases, such as Alzheimer's (e.g. through inhibiting the $A \beta$ accumulation and APP processing, and inducing amelioration of tau hyperphosphorilation via PP2A, GSK3 $\beta$ pathways in N2a/APP cells).

\subsection{Silicon}

Silicon, in the form of silicic acid or orthosilicic acid, is mainly found in whole grains (e.g., cereals) and fiber-rich foods. Therefore, due to its production ingredients, beer is one of the main silicon dietary source $[88,119]$.

Although the health benefits of silicon, with regard to skeletal and neurological function and status, have already been recognized [149], there is currently limited available information regarding the possible beneficial effects of silicon on neural toxicity. In this regard, recent papers of our group (Table 4) have clearly demonstrated the antioxidant properties of silicon in neuroblastoma cells and rat's liver $[128,150]$.

Noremberg et al. [18] showed that intraperitoneal administration of silicon in similar concentrations to those found in parenteral nutrition reduces the harmful effects of increased lipoperoxides (LPO) in rat brain induced by long-term aluminum exposure. This finding is relevant because of oxidative stress, and increased LPO levels in cerebral tissue are major factors in the development of neurodegenerative diseases [151]. The reduction of TBARS levels by the administration of silicon strongly suggests the neuroprotective effect of this metal. Silicon was also effective in reducing the LPO, since the formation of hydroxyaluminosilicates may reduce aluminum availability, leading to a decrease in ROS generation. Therefore, silicon could be considered a protector against aluminum-associated neurological diseases [126]. 


\section{Effects of Beer on Aluminum Bioavailability}

Silicon and silicic acid may decrease aluminum bioavailability by partially blocking its gastrointestinal tract uptake [152] and by impeding its reabsorption [153]. According to Gillette Guyonnet et al. [127], silica is probably the natural antidote of aluminum and could play a beneficial role by decreasing aluminum bioavailability. These authors suggest the possible use of silicates as a therapeutic agent for Alzheimer's disease, since both model tangles and precipitated $\beta$-pleated sheets of $A \beta 4$ can be reversed to soluble forms by silicates. Likewise, the same authors found that silica in drinking water might reduce the risk of developing Alzheimer's disease [126].

More than one decade ago, it was demonstrated that beer intake affected the kinetics of aluminum uptake and excretion. A three-day shot-term study in male mice subjected to the conjoint administration of aluminum $(450 \mu \mathrm{g} / \mathrm{ml})$ and two doses of beer, one equivalent to moderate-low consumption in humans $(0.5 \mathrm{~L} / \mathrm{d})$ and another equivalent to moderate-high consumption in humans $(1 \mathrm{~L} / \mathrm{d})$, was performed [120]. Following this study, a long-term test was formulated to substantiate the possible protective action of beer against chronic aluminum exposure and accumulation in brain tissue. Results demonstrated that silicic acid and beer affected the kinetics of aluminum uptake and excretion, possibly through an interaction between aluminum and silicon in the digestive tract. Moreover, silicic acid did not only reduce the aluminum gastrointestinal absorption but also increased the aluminum release and excretion from the body. In fact, the aluminum group excreted significantly lower fecal aluminum than the aluminum-beer and aluminum-silicon groups $(487.7 \pm 70.8 \mu \mathrm{g} / \mathrm{g}$ feces vs. $581.0 \pm 92.6$ and $665.9 \pm 160.4$, respectively) [122]. Therefore, it was hypothesized that silicon in the form of silicic acid may lower aluminum bioavailability and hence should be considered an element that may afford protection against aluminum intoxication.

The dietary o-silicic acid supplement was efficient in lowering aluminum brain depots in the aluminum-silicon mice to the same values observed in the basal group. Similarly, although not significantly, the administration of beer tended to decrease the aluminum content in the brain. These results suggest that beer intake did not produce the same increase in brain silicon levels as the dietary silicon supplement did. Nonetheless, based on these results, it must be suggested that silicon administration appears effective in preventing aluminum accumulation in mouse brain, as was previously reported by Granero et al. [121].

Figure 5 shows some relevant insights of a mouse brain intoxicated with aluminum [122]. Thus, white matter spongiosis but no neuronal necrosis was observed in the positive aluminum control mice (a). Aluminum-dosed animals treated with silicon showed necrosis both in the cortex and in the cerebellum (b). By contrast, the brains of the mouse that received conjoint administration of aluminum and beer exhibited necrosis of cortical neurons (c). Although the results clearly suggest more advanced lesions in the aluminum-intoxicated mice, it was concluded that more detailed studies of longer duration should be further performed, to validate the pathologic repercussions found.



Figure 5. Histological examination of a mouse brain intoxicated with aluminum. (a) Spongiosis but no neuronal necrosis in the positive aluminum control mice; (b) necrosis in the cortex and in the cerebellum of aluminum-intoxicated animals treated with silicon; (c) necrosis of cortical neurons of animals treated with conjoint aluminum and beer [122] (Elsevier copyright license number: 4621240772368). 
As already commented on, the effectiveness of silicon could be attributed to its interaction with aluminum through the formation of nontoxic aluminosilicate complexes that decrease free aluminum availability. A number of biological sites have been identified, in which silicon and aluminum are co-deposited or co-localized. Among them, the senile plaque cores in the cerebral cortex of patients suffering from senile dementia/Alzheimer's type have been more deeply investigated. High-resolution solid-state nuclear magnetic resonance measurements on the central regions of these plaques have shown that silicon and aluminum are present as an aluminosilicate species as a way to partially block aluminum toxicity [154]. Plaque structures have also been observed in mentally normal elderly patients, and the use of dietary silicon supplements as a preventive measure for Alzheimer's disease has been suggested [155].

\section{Effect of Beer on Brain Antioxidant and Inflammatory Status}

Taking into account the relationships between aluminum exposure, oxidative stress, inflammation, and certain neurological disorders already commented on, our research group also carried out studies to evaluate the neuroprotective effect of beer itself and by means of its major components (silicon and hops) on the oxidative and inflammatory alterations induced by aluminum intoxication in mice. Changes in gene expression of some antioxidant enzymes and inflammatory factors were evaluated in the brains of different mice groups that distinctly received aluminum plus beer, aluminum plus silicon or simply aluminum for 3 months [48]. Results showed that inclusion of silicon in the diet in the form of beer or silicic acid reduces the harmful effects of increased cerebral peroxidation by lowering aluminum levels in the brain. In addition, silicon, silicic acid or beer highly blocked the prooxidant and pro-inflammatory actions of aluminum by decreasing brain TBARS levels and glutathione peroxidase (GPx) and tumor necrosis factor-alpha (TNF $\alpha$ ) expressions but increasing the superoxide dismutase (SOD) and catalase (CAT) enzyme expressions. Thus, the changes on redox status induced by beer or silicon consumptions seem to be related with an adequate ROS production, giving rise to a correct reduced-oxidized glutathione (GSH-GSSG) balance. These findings are relevant, as oxidative stress and increased lipid peroxidation in the brain are the major contributing factors for neurodegenerative disease development [17,156-158]. The administration of silicic acid or beer reduced TBARS levels, strongly suggesting the neuroprotective properties of silicon. Interestingly, brain gene expressions of $\mathrm{Mn}-\mathrm{SOD}, \mathrm{Cu} / \mathrm{Zn}-\mathrm{SOD}$, and CAT were positively correlated with one another, but all of them negatively with GPx gene expression, supporting the hypothesis that ingestion of silicon has beneficial effects against aluminum intoxication [48].

The lower TNF $\alpha$ expression in the silicic acid and beer groups with respect to the aluminum group and the control group newly suggests the existence of a detoxification mechanism. These results were suggested in previous studies to be related with a successful chelation of aluminum, followed by its mobilization and excretion from the body as previously discussed [122]. Winkler et al. [117] reported that beer components act as anti-inflammatory agents by reducing the effects mediated by pro-inflammatory cytokine interferon-gamma (IFN- $\gamma$ ), and as antioxidant through reducing ROS formation. In fact, hops, due to their high polyphenol content, have been found to exert anti-inflammatory effects [76].

Although results due to silicon administration were very relevant, the role of other compounds present in beer, as hops, some polyphenols, folic acid, melatonin, and alcohol, cannot be ruled out. In fact, hops have been found to be a relevant source of resveratrol that could partially explain the improvement of the antioxidant status in beer-administrated mice [125]. In addition, hops decrease production of TBARS and carbonyl groups in the elderly [159]. Folic acid is responsible, through cystathionine- $\beta$ synthase, for producing cysteine, a precursor of glutathione that exerts antioxidant properties. Moreover, hyperhomocysteinemia - a condition related to low folic acid bioavailability-increased generation of free radicals [160], and several studies in humans have reported an inverse association between homocysteine and cognitive impairment or dementia [161,162]. 
Another interesting beer compound is melatonin [132]. Maldonado et al. [129] suggested that the melatonin present in beer does contribute to the total antioxidant ability of human serum. Therefore, melatonin can directly act as a free radical scavenging and indirectly stimulating the role of some antioxidant enzymes (e.g., SOD, GPx, GR) which, in turn, will reduce the toxicity of radicals and their associated reactants [163]. In addition, melatonin reduced $A \beta$-induced oxidative stress and the level of IL6 and IL1- $\beta$ pro-inflammatory cytokines in in vivo studies $[132,133,164]$.

\section{Effect of Beer on Metal Homeostasis in the Brain}

Emerging data suggest that aluminum may heighten some events associated with neurodegenerative diseases by inducing mineral imbalance [165]. According to Colomina and Peris-Sampedro [17], the interaction between aluminum and iron modifies iron homeostasis by increasing the intracellular pool of free iron, releasing it from the iron-containing enzymes and proteins, which in turn contributes to a higher ROS production. Maintaining transition metal homeostasis is known to be important in a wide variety of biological functions, such as antioxidant defense mechanisms. Aiming to shed some light on the effect of aluminum on brain metal homeostasis, we evaluated in mice the effect of aluminum exposure on copper, iron, magnesium, manganese, silicon, zinc, and aluminum brain contents and the correlations between those metal levels and some antioxidant status and inflammation markers. In addition, by means of statistical models, we elucidated potential mechanisms that will contribute to explaining the role of the brain metal content on brain toxicity [43]. Aluminum nitrate exposition significantly increased silicon contents in mouse brains but decreased copper, manganese, and zinc levels. Under aluminum nitrate exposition, beer or silicic acid significantly lowered aluminum and silicon levels and normalized those of copper, manganese, and zinc in the brain. The nonsignificant effects found on iron can be partially explained, according to Colomina and Peris-Sampedro [17], based on that aluminum generates labile iron from enzymes and proteins but does not change the total iron content of the brain. A principal component study (PCA) performed considering mouse groups, brain metals, and brain oxidative/inflammatory profiles showed that the aluminum group was clearly separated from control animals, while aluminum-beer and aluminum-silicon were placed closer to control mice, suggesting a partial block of aluminum pro-oxidant effects. On the other hand, pro-oxidant markers in the brain connected with the brain aluminum content and, to a lesser extent, with that of silicon. By contrast, zinc and copper brain levels were closer to the antioxidants' enzyme activities (Figure 6). Thus, it can be highlighted that the conjoint administration of aluminum nitrate and silicic acid or beer partially blocked the metal disbalance induced by aluminum nitrate and reversed the inflammatory and oxidant/antioxidant status of the mouse's brain. Such a blocking effect joined to the impact of silicic acid/beer on aluminum nitrate absorption justifies the importance of adjusting dietary silicon levels to aluminum intake. 


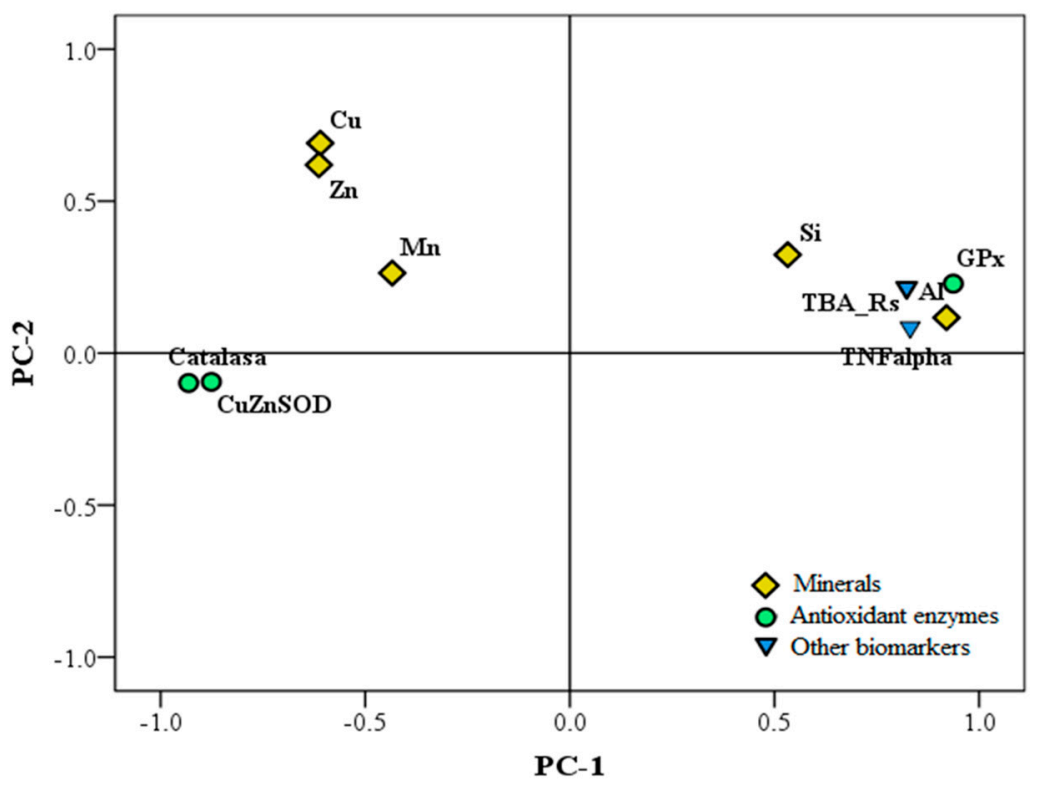

Figure 6. Principal component analysis (PCA) plot of the minerals, oxidation, and inflammation biomarkers of mouse's brains. The co-administration of aluminum and silicon or beer partially blocked the metal disbalance and reversed the inflammatory and oxidative status in the mouse brain.

\section{Effect of Non-Alcoholic Beer, Silicon, and Hops on Brain Damage and Behavioral Changes Induced by Aluminum}

The previous results clearly show the benefits of beer consumption, so it would be appropriate to recommend it as a way to alleviate the deleterious effects of aluminum exposure on the brain. However, regular beer should not be recommended to some population sectors (e.g., pregnant women, metabolic syndrome patients, non-alcoholic fatty liver patients) due to its alcohol content [166]. Therefore, our research group conducted a new study on the capacity of non-alcoholic beer (NA-beer) and its components (silicon and hops) to enhance brain antioxidant and inflammatory status, which in turn would help with improving brain functions, improving the impaired learning ability, and motility caused by aluminum intoxication. In addition, the in vitro antioxidant capacity and the inhibition of acetylcholinesterase activity of NA-beer and its two main ingredients, silicon and hops, were evaluated [123].

Results of that study clearly show that the incorporation of aluminum nitrate plus NA-beer or its hops and silicon components significantly reduced the negative effects caused by aluminum nitrate administration on the behavior of rats and the brain's inflammatory and antioxidant markers. The behavior assessment was performed according to a standard battery test. In the hole-board task, we evaluated curiosity, immobility time, grooming frequency, and the defecation index. Grooming was interpreted as a way to release tension, defecation rate indicated the emotive grade as an intestinal tonus and peristalsis increase, and immobility was related to transitory hyperactivity [167]. The pain threshold was evaluated throughout the hot plate test [168]. Merino et al. [123], in order to highlight differences between groups, performed MANOVA tests on the behavioral experiment battery tests and found that aluminum + NA-beer and aluminum + silicon did not significantly differ when compared to the control group, while aluminum + hops significantly differs in comparison with all other groups.

These tendencies were clearly demonstrated after testing behavior results by the principal components analysis for categorical data (CATPCA) in order to identify patterns and highlight relationships and to observe group distribution differences (optimum group scaling was: 1, control group; 2, aluminum nitrate-treated group; 3 , aluminum nitrate plus non-alcoholic beer; 4 , aluminum nitrate plus hops extract; 5 , aluminum nitrate plus silicon).

On the basis of a stability study, two major components were found that explained $73.3 \%$ of total data variance $(43.2 \%$ for the first one and $31.1 \%$ for the second one (Figure 7 ). Two subscales, 
positive and negative, for each component, explaining the contribution to the model, were drawn. For the first dimension, forced swimming and group scaling were the variables that most negatively contributed, while immobility time at forced swimming, immobility, and reaction time at the hot plate test, the variables that most positively contributed to the model. For the second dimension, rearing, curiosity, and group scaling most negatively contributed, while grooming, fecal index, and immobility most positively contributed to the model. The ellipses drawn help to identify data for the different experimental groups in comparison to their control counterpart and aluminum groups. The first dimension separates aluminum behavioral data from those of aluminum + silicon and aluminum + NA-beer. The second dimension separates the behavioral data of the aluminum group from those of the control group. Results also suggest a new role for NA-beer and its components, as the administration of NA-beer, hops, and silicon together with aluminum nitrate was effective in preventing the detrimental effect of this metal on memory decline. This preventive effect was also clearly shown in the CATPCA test evaluating behavior as the aluminum group data were sharply separated from the control and all treated groups. In addition, some related measurements (e.g., hot plate time reaction and fecal index changes) contributed similarly to the multivariate model applied, supporting the validity of the battery test performed in the present study.

According to relevant research, aluminum interacts with the cholinergic system, acting as a cholinotoxin. The intensification of inflammation and the interference with cholinergic projection functions may represent the way by which it contributes to pathological processes in Alzheimer's disease, leading to learning and memory deficits [169] and explaining the negative effects on curiosity, immobility time, grooming frequency, defecation rate, and forced swimming on aluminum intoxicated rats observed in our study.

The in vivo test showed that behavioral improvements observed after the administration of NA-beer and its components in this study appear to be clearly associated with the in vitro results obtained from AChE and buthylcholinesterase (BChE) by our research group testing silicon in human neuroblastoma cells [128], suggesting that potential improvements in cholinesterase levels were involved and that silicon was one of the major factors responsible for this inhibition effect. In fact, Jacqmin-Gadda et al. [170] indicated that an association exists between cognitive impairment and brain pH, aluminum, and silica. Noremberg et al. [18] described a protective effect of silicon on the hippocampus (region of the brain traditionally linked with learning and memory control) and cerebellum against cellular damage caused by aluminum-induced oxidative stress, by the measure of lipoperoxides (LPO). An increase of AChE activity was observed in the aluminum-treated group in the cerebellum, whereas a decrease of this enzyme activity was observed in the cortex and hippocampus in the aluminum and aluminum + silicon groups.

In line with the González-Muñoz et al. [43] study, aluminum nitrate intoxication impairs the brain antioxidant status. Noremberg et al. [18], based on many investigations, suggested that the brain may be particularly vulnerable to oxidative damage due the relationship between aluminum accumulation and oxidative damage in the brain [171]. As previously commented on, although aluminum is not a transition metal and therefore cannot initiate peroxidation, aluminum induces alteration in brain metal homeostasis [17], mainly affecting minerals with antioxidant properties [40]. High TBARS values and alteration in the antioxidant enzyme activity and expression observed in the brains of the aluminum group corroborate the pro-oxidant effects of aluminum and suggest the relative failure of antioxidant mechanisms. Martínez et al. [53], after a subchronic study, concluded that aluminum increased hippocampal reactive oxygen species and lipid peroxidation, reduced antioxidant capacity, and decreased AChE activity. This would explain the memory impairment and neurotoxicity. 

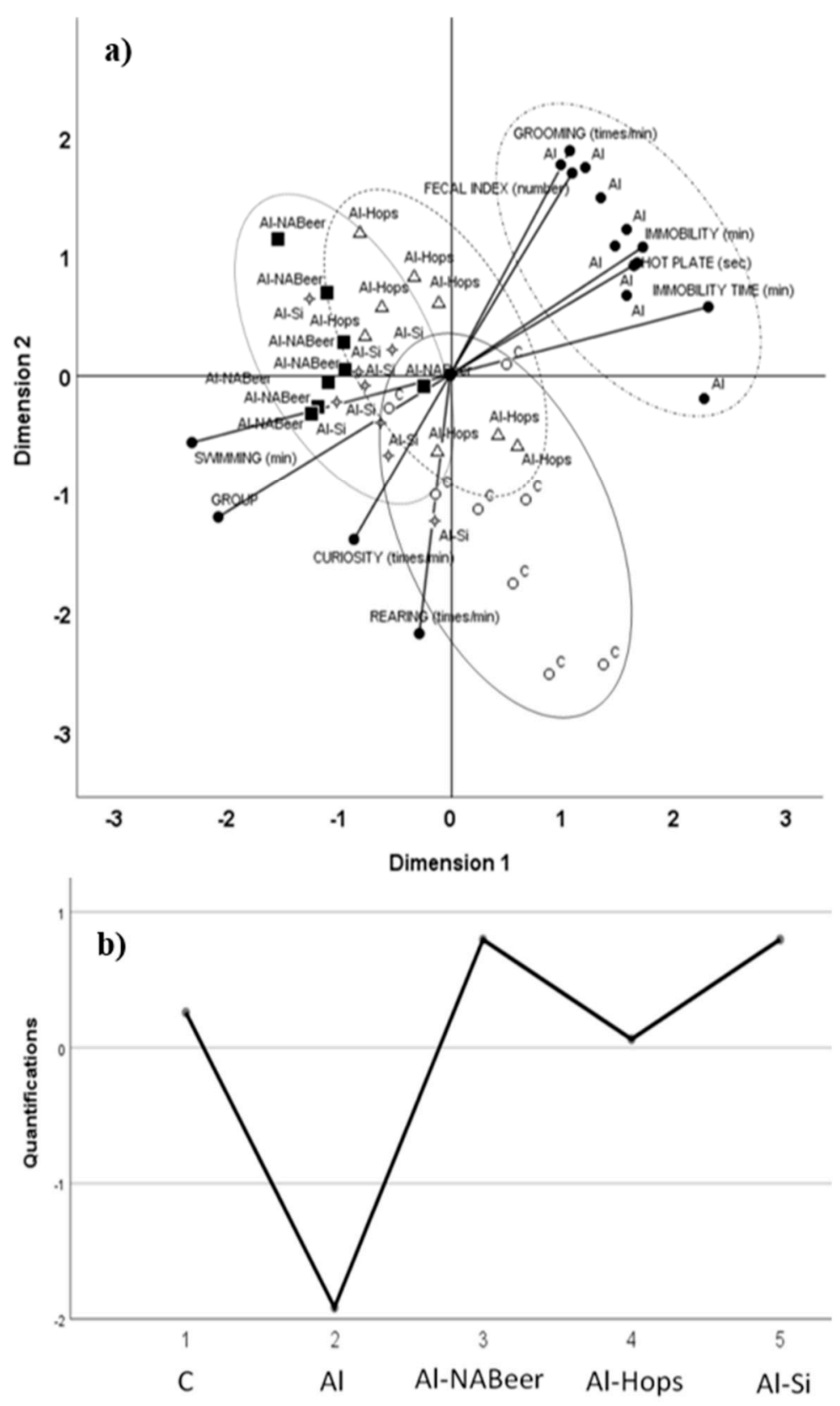

Figure 7. (a) Categorical principal component analysis (CATPCA) scatter biplot using groups and nine behavioral variables: rearing, immobility, curiosity, grooming, fecal index, swimming time at the forced swimming test (swimming), immobility time at the forced swimming test, and reaction time (hot plate). (b) Optimal scaling level for the different groups: 1, control group; 2, aluminum-treated group; 3, aluminum plus non-alcoholic beer; 4 , aluminum plus hops extract; and 5, aluminum plus silicon. The first and second dimensions accounted for $43.2 \%$ and $31.1 \%$ of variance, respectively (3.89 and 2.80, respective Eigen values). The ellipses drown surround data for each of the different experimental groups [123].

Inhibition of TBARS by administration of aluminum + silicon or aluminum + NA-beer strongly suggests the neuroprotective properties of silicon and beer compounds against aluminum intoxication. According to Noremberg et al. [18], silicon may be considered an important protector against lipid peroxidation induced by $\mathrm{Al}^{3+}$. Figure 8 summarizes changes in the redox defense mechanism and the antioxidant enzymes' activities and expressions. Aluminum intoxication significantly increased the SOD expression as a way to eliminate the produced superoxide ion, while due to the lower GR activity 
and expression and the higher GPx activity, GSH decreased. The conjoint administration of aluminum NA-beer, silicon, and hops displays similar profiles for antioxidant enzyme activity and expressions. NA-beer, hops extract, and silicon treatment appear to prevent aluminum-induced augmented lipid peroxidation and changes in GSH, GSSG, and redox index levels [123], probably by contributing both with antioxidants (e.g., phenolic compounds, flavonoids, tannins) (Tables 2 and 3) or through the effect of silicon modulating the antioxidant enzyme expressions $[43,150]$. In addition, the conjoint administration of aluminum with hops, silicon or beer affected the inflammatory status in a quite similar manner. The differences observed between the battery test for behavior and antioxidant and inflammatory status clearly indicate the complexity of the effects tested and suggest the interaction of treatments on neurotransmitter changes (e.g., acetylcholine). Thus, hops clearly differentiate from beer and silicon at the behavior test with no differences with respect to the aluminum group, while exerting similar antioxidant and anti-inflammatory actions as silicon and Na-beer.



Figure 8. Summary of the main effect of aluminum intoxication on the antioxidant enzymes' activities and expressions in the rats' brains [123]. Colored arrows indicate significant differences caused by the aluminum-treated group when compared to the experimental groups. CAT, catalase; SOD, superoxide dismutase; GR, glutathione reductase; GPx, glutathione peroxidase; GSH, reduced glutathione; GSSG, oxidized glutathione. Subsections: (a) comparison between the Aluminium intoxicated group with their control counterparts; (b) comparison between the Aluminium intoxicated group with the Aluminium + Non-alcoholic beer group; (c) comparison between the Aluminium intoxicated group with the Aluminium + Hops extract group; (d) comparison between the Aluminium intoxicated group with the Aluminium + Silicon group.

\section{Conclusions}

Taking into account all previous discussed results, we can reach the following conclusions:

- In vitro and in vivo models are plausible tools to study brain mechanisms related to changes in behavior, Alzheimer's disease, and dementia.

- Aluminum induces several mechanisms engaged to brain damage and behavioral disturbances, through mechanisms that mainly involve apoptosis, tau phosphorylation, $\mathrm{A} \beta$ accumulation, 
ROS formation, necrosis of neuronal cells, regulation of metal imbalance, and changes in the antioxidant defense system.

- The conjoint addition of aluminum and beer, or its ingredients and compounds, proved that they can partially block the negative effects of neurodegeneration or neurotoxics, such as aluminum, in several cell, rodent, and human models.

- Due to its alcohol content, regular beer consumption can be non-adequate for some risk-group populations (pregnancy, children, people affected by liver diseases), and the consumption of non-alcoholic beer is highly recommended instead of regular beers.

- Given the results observed by our groups and others, dementia or the pathognomic factors can be blocked by promoting increased levels of silicon consumption in aluminum-intoxicated patients.

- As silicon is "attracted by" the presence of aluminum at the intestine and brain, among other body places, strategies should be formulated to adjust silicon consumption to aluminum exposure and to increase the brain uptake of silicon.

In summary, regular beer consumption could constitute a non-invasive preventive measure for the prevention of Alzheimer's disease and other neurodegenerative diseases, since it is effective in reducing the aluminum body load, as well as in alleviating the mineral homeostasis imbalance in the brain and the pro-oxidant and pro-inflammatory effects induced by that metal. However, regular beer, due to its alcohol content, might not be adequate for consumption in all human beings. Thus, the study of non-alcoholic beer properties and their application as a preventive tool for degenerative disease is highly demanded.

\section{Future Remarks}

Future studies should be focused on analyzing how the presence of different levels of silicon, hops, polyphenols, melatonin in beer, and their interactions affect the metabolizing capability of both alcohol-metabolizing and antioxidant enzymes. In addition, the bioavailability of silicon differs depending on its food origin and chemical state [25].

Taking into account the ample beer consumption in the world and the increased prevalence of dementia, future investigation should be addressed at understanding the intimate mechanisms implicated in different alteration pathways leading to dementia and the most powerful mechanisms by which beer could slow down the development of dementia and Alzheimer's disease.

Early markers (BDNF, pancreatic amyloid, Nrf2, receptor of advanced glycosylation end products-RAGE) should be tested to improve prevention and delete or avoid the negative consequences of dementia in animal models and even in human beings with a special study of the interaction of $A \beta$ with glial cells. The role of beer and its compounds on these earlier markers should be investigated. The most beneficial compounds of beer should be concentrated and their bioavailability improved while the theoretical negative compounds deleted to obtain a functional beer capable of slowing down the dementia progression in animal models and human populations.

Nutrigenomic studies should be performed and their results tested and studied in ample gen spectrum microchips. Genes related with carbohydrate and lipid metabolisms and adipogenesis (e.g., PPAR $\gamma$ ), mitochondrogenesis, and autophagy will be researched. As some dietary compounds and lifestyle are implicated in the expression of BDNF [172], the role of beer and their compounds in this neurotrophic factor will also be studied. As ethanol differently affects people depending on its metabolization rate and that of acethaldehyde [173], studies on the possible deleterious/protective effect of regular beer consumption should address quick and slow alcohol metabolizers, studying the presence of gene polymorphisms for the alcohol dehydrogenase (ADH1B exon 3), aldehyde dehydrogenase (ALDH2 1), CAT, and for the major isoenzyme of the P450 isoforms (CYP2E1) and their interaction with major gene polymorphisms related to Alzheimer's disease (e.g., ApoE, APP, PS-1, PS2, CLU, gen receptor of efrina A1 EPHA1, ATP Binding Cassette A7) [174]. In addition, differences in response to beer and beer compounds will be tested according to GWAS and EGWAS [175]. 
As recent studies have suggested a potential link between intestinal microflora composition and function and brain health [176-178], specific studies should also study how different types of beer can affect brain health through modifying colonic microflora profile and abundance.

The benefits of one-a-day alcoholic beer, low alcohol content, and non-alcoholic beer versus abstention in an ample range of ages both in male and female health or differently affected by different dementia degrees or by degenerative diseases having Alzheimer's disease or dementia as comorbidity (e.g., diabetes) should be tested in long-term studies.

Author Contributions: Conceptualization, F.J.S.-M., J.B. and M.J.G.-M.; Bibliographic research A.M.-G., A.G. and J.A.S.-L.; Data Curation, F.J.S.-M., J.B., S.B. and M.J.G.-M.; Writing-Original Draft Preparation, A.M.-G., A.G. and J.A.S.-L.; Writing-Review \& Editing, F.J.S.-M., J.B. and M.J.G.-M.; Supervision, F.J.S.-M.; Funding Acquisition, F.J.S-M. and J.B.

Funding: This research was funded by the project Santander-UCM, grant number PR75/18-21603.

Conflicts of Interest: The authors declare no conflict of interest.

\section{Abbreviations}

$\mathrm{A} \beta$, amyloid beta peptide; AChE, acethylcholinesterase; APO-E, apolipoprotein E; AP, amyloid beta protein; APP, amyloid precursor protein; BChE, buthylcholinesterase; BDNF, brain-derived neurotrophic factor; CAT, catalase; GPx, glutathione peroxidase; GSH, reduced glutathione; GSSG, oxidized glutathione; LPO, lipoperoxides; MD, Mediterranean diet; NA-beer, non-alcoholic beer; PPAR- $\gamma$, peroxisome proliferator-activated receptor gamma; IFN- $\gamma$, pro-inflammatory cytokine interferon-gamma; ROS, reactive oxygen species; SOD, superoxide dismutase; TBARS, tiobarbituric acid reactive substances; TNF $\alpha$, tumor necrosis factor-alpha; HSV-1, type I herpes simplex virus.

\section{References}

1. Prince, M.; Ali, G.C.; Guerchet, M.; Prina, A.M.; Albanese, E.; Wu, Y.T. Recent global trends in the prevalence and incidence of dementia, and survival with dementia. Alzheimers Res. Ther. 2016, 30, 23. [CrossRef] [PubMed]

2. World Health Organization (WHO). Risk Reduction of Cognitive Decline and Dementia: WHO Guidelines; WHO: Geneva, Switzerland, 2019.

3. Blennow, K.; de Leon, M.J.; Zetterberg, H. Alzheimer's disease. Lancet 2006, 368, 387-403. [CrossRef]

4. Cuervo, A.M.; Wong, E. Chaperone-mediated autophagy: Roles in disease and aging. Cell Res. 2014, 24, 92-104. [CrossRef] [PubMed]

5. Sánchez-Villegas, A.; Galbete, C.; Martínez-González, M.A.; Martinez, J.A.; Razquín, C.; Salas-Salvadó, J.; Estruch, R.; Buil-Cosiales, P.; Martí, A. The effect of the Mediterranean diet on plasma brain-derived neurotrophic factor (BDNF) levels: The PREDIMED-NAVARRA randomized trial. Nutr. Neurosci. 2014, 14, 195-201. [CrossRef] [PubMed]

6. Gosche, K.M.; Mortimer, J.A.; Smith, C.D.; Markesbery, W.R.; Snowdon, D.A. Hippocampal volume as an index of Alzheimer neuropathology: Findings from the nun study. Neurology 2002, 58, 1476-1482. [CrossRef] [PubMed]

7. Barnes, D.E. The Mediterranean diet: Good for health good for the brain? Ann. Neurol. 2011, 69, $226-228$. [CrossRef] [PubMed]

8. Xu, W.L.; Atti, A.R.; Gatz, M.; Pedersen, N.L.; Johansson, B.; Fratiglioni, L. Midlife overweight and obesity increase late-life dementia risk: A population-based twin study. Neurology 2011, 76, 1568-1574. [CrossRef] [PubMed]

9. Medina-Santillán, R.; Martínez-Sámano, J. Implicaciones de la obesidad: Neuroinflamación y neurodegeneración [Obesity implications: Neuroinflammation and Neurodegenaration]. In IV y V Cursos Avanzados Sobre Obesidad y Sindrome Metabólico; Sánchez-Muniz, F.J., Bastida, S., Gesteiro, E., Garcimartín, A., Eds.; Real Academia Nacional de Farmacia e Instituto de España: Madrid, Spain, 2018; pp. 101-116.

10. Nuzzo, D.; Picone, P.; Baldassano, S.; Caruana, L.; Messina, E.; Marino Gammazza, A.; Di Carlo, M. Insulin resistance as common molecular denominator linking obesity to Alzheimer's disease. Curr. Alzheimers Res. 2015, 12, 723-735. [CrossRef] 
11. Nuzzo, D.; Amato, A.; Picone, P.; Terzo, S.; Galizzi, G.; Bonina, F.; Di Carlo, M. A natural dietary supplement with a combination of nutrients prevents neurodegeneration induced by a high fat diet in mice. Nutrients 2018, 10, 1130. [CrossRef]

12. Sánchez-Muniz, F.J.; Simón, C. Clock genes, chronodysruption, nutrition and obesity. Curr. Res. Diabetes Obes. J. 2017, 3, 555607.

13. García-Huerta, P.; Troncoso-Escudero, P.; Jerez, C.; Hetz, C.; Vidal, R.L. The intersection between growth factors, autophagy and ER stress: A new target to treat neurodegenerative diseases? Brain Res. 2016, $1649 \mathrm{Pt}$ B, 173-180. [CrossRef] [PubMed]

14. Valero, T. Mitochondrial Biogenesis: Pharmacological Approaches. Curr. Pharm. Des. 2014, 20, 5507-5509. [CrossRef] [PubMed]

15. Miklossy, J. Emerging roles of pathogens in Alzheimer disease. Exp. Rev. Mol. Med. 2011, 13, e30. [CrossRef] [PubMed]

16. Goyer, R.A. Toxic and essential metal interactions. Ann. Rev. Nutr. 1997, 17, 37-50. [CrossRef] [PubMed]

17. Colomina, M.T.; Peris-Sampedro, F. Aluminium and Alzheimer disease. Adv. Neurobiol. 2017, 18, $183-197$. [PubMed]

18. Noremberg, S.; Bohrer, D.; Schetinger, M.R.; Bairros, A.V.; Gutierres, J.; Gonçalves, J.F.; Veiga, M.; Santos, F.W. Silicon reverses lipid peroxidation but not acetylcholinesterase activity induced by long-term exposure to low aluminum levels in rat brain regions. Biol. Trace Elem. Res. 2016, 169, 77-85. [CrossRef] [PubMed]

19. Kumar, A.; Singh, A. A review on Alzheimer's disease pathophysiology and its management: An update. Pharmacol. Rep. 2015, 67, 195-203. [CrossRef]

20. El-Swefy, S.H.; Atteia, H.H. Molecular aspects of the Mediterranean diet: Adiponectin, brain, amyloid precursor protein, apolipoprotein E and Caspase-3 mRNA. In The Mediterranean Diet: An Evidence-Based Approach; Preedy, V., Watson, R., Eds.; Elsevier: Amsterdam, The Netherlands, 2015; pp. 441-453.

21. Hersi, M.; Irvine, B.; Gupta, P.; Gomes, J.; Birkett, N.; Krewski, D. Risk factors associated with the onset and progression of Alzheimer's disease: A systematic review of the evidence. Neurotoxicology 2017, 61, 143-187. [CrossRef]

22. Campbell, A. The role of aluminum and cooper on neuroinflammation and Alzheimer's disease. J Alzheimers Dis. 2006, 10, 165-172. [CrossRef]

23. Perry, C.C.; Keeling-Tucker, T. Aspects of the bioinorganic chemistry of silicon in conjunction with the biometals calcium, iron and aluminum. J. Inorg. Biochem. 1998, 69, 181-191. [CrossRef]

24. Aikoh, H.; Nakamura, K.; Yamato, M.; Shibahara, T. Studies on the amount of aluminum and calcium administration with and without amino acid. Physiol. Chem. Phys. Med. NMR 2005, 37, 65-69.

25. Baydar, T.; Papp, A.; Aydin, A.; Nagymajtenyi, L.; Schulz, H.; Isimer, A.; Sahin, G. Accumulation of aluminum in rat brain: Does it lead to behavioral and electrophysiological changes? Biol. Trace Elem. Res. 2003, 92, 231-244. [CrossRef]

26. Rondeau, V.; Iron, A.; Letenneur, L.; Commenges, D.; Duchene, F.; Arveiler, B.; Dartigues, J.F. Analysis of the effect of aluminum in drinking water and transferrin $C 2$ allele on Alzheimer's disease. Eur. J. Neurol. 2006, 13, 1022-1025. [CrossRef] [PubMed]

27. Inan-Eroglu, E.; Ayaz, A. Is aluminum exposure a risk factor for neurological disorders? J. Res. Med. Sci. 2018, 23, 51. [PubMed]

28. Yuan, C.Y.; Lee, Y.J.; Hsu, G.S. Aluminium overload increases oxidative stress in four functional brain areas of neonatal rats. J. Biomed. Sci. 2012, 19, 51. [CrossRef] [PubMed]

29. Nübling, G.; Bader, B.; Levin, J.; Hildebrandt, J.; Kretzschmar, H.; Giese, A. Synergistic influence of phosphorylation and metal ions on tau oligomer formation and coaggregation with $\alpha$-synuclein at the single molecule level. Mol. Neurodegener. 2012, 23, 35. [CrossRef]

30. Oshiro, S.; Kawahara, M.; Kuroda, Y.; Zhang, C.; Cai, Y.; Kitajima, S.; Shirao, M. Glial cells contribute more to iron and aluminum accumulation but are more resistant to oxidative stress than neuronal cells. Biochim. Biophys. Acta 2000, 1502, 405-414. [CrossRef]

31. Exley, C. A molecular mechanism of aluminum-induced Alzheimer's disease? J. Inorg. Biochem. 1999, 76, 133-140. [CrossRef]

32. Kawahara, M. Effect of aluminum on the nervous system and its possible link with neurodegenerative diseases. J. Alzheimers Dis. 2005, 8, 171-182. [CrossRef] 
33. Perl, D.P.; Moalem, S. Aluminium and Alzheimer's disease, a personal perspective after 25 years. J. Alzheimers Dis. 2006, 9, 291-300. [CrossRef]

34. McLachlan, D.R.; Bergeron, C.; Alexandrov, P.N.; Walsh, W.J.; Pogue, A.I.; Percy, M.E.; Kruck, T.P.A.; Fang, Z.; Sharfman, N.M.; Jaber, V.; et al. Aluminium in Neurological and Neurodegenerative Disease. Mol. Neurobiol. 2019, 56, 1531-1538. [CrossRef] [PubMed]

35. Kawahara, M.; Kato-Negishi, M. Link between aluminum and the pathogenesis of Alzheimer's disease: The integration of the aluminum and amyloid cascade hypotheses. Int. J. Alzheimers Dis. 2011, 2011, 276393. [CrossRef] [PubMed]

36. Walton, J.R. Aluminium in hippocampal neurons from humans with Alzheimer's disease. Neurotoxicology 2006, 27, 385-394. [CrossRef] [PubMed]

37. Bolognin, S.; Messori, L.; Zatta, P. Metal ion physiopathology in neurodegenerative disorders. Neuromol. Med. 2009, 11, 223-238. [CrossRef] [PubMed]

38. Exley, C. The aluminum-amyloid cascade hypothesis and Alzheimer's disease. Subcell Biochem. 2005, 38, 225-234. [PubMed]

39. Exley, C. Aluminium and iron, but neither copper nor zinc, are key to the precipitation of beta-sheets of Abets in senile plaque cores in Alzheimer's disease. J. Alzheimers Dis. 2006, 10, 173-177. [CrossRef]

40. Pratico, D.; Uryu, K.; Sung, S.; Tnag, S.; Trojanowski, J.Q.; Lee, V.M. Aluminium odulates brain amyloidosis though oxidative stress in APP transgenic mice. FASEB J. 2002, 16, 1138-1140. [CrossRef]

41. Bondy, S.C.; Kirstein, S. The promotion of iron-induced generation of reactive oxygen species in nerve tissue by aluminum. Mol. Chem. Neuropathol. 1996, 27, 185-194. [CrossRef]

42. Becaria, A.; Campbell, A.; Bondy, S.C. Aluminium and copper interact in the promotion of oxidative but not inflammatory events: Implications for Alzheimer's disease. J. Alzheimers Dis. 2003, 5, 31-38. [CrossRef]

43. González-Muñoz, M.J.; Garcimartín, A.; Meseguer, I.; Mateos-Vega, C.J.; Orellana, J.M.; Peña-Fernández, A.; Benedí, J.; Sánchez-Muniz, F.J. Silicic acid and beer consumption reverses the metal imbalance and the prooxidant status induced by aluminum nitrate in mouse brain. J. Alzheimers Dis. 2017, 56, 917-927. [CrossRef]

44. Fattoretti, P.; Bertoni-Freddari, C.; Balietti, M.; Giorgetti, B.; Solazzi, M.; Zatta, P. Chronic aluminum administration to old rats results in increased levels of brain metal ions and enlarged hippocampal mossy fibers. Ann. N. Y. Acad. Sci. 2004, 1019, 44-47. [CrossRef] [PubMed]

45. Sánchez-Iglesias, S.; Méndez-Alvarez, E.; Iglesias-González, J.; Muñoz-Patiño, A.; Sánchez-Sellero, I.; Labandeira-García, J.L.; Soto-Otero, R. Brain oxidative stress and selective behaviour of aluminum in specific areas of rat brain: Potential effects in a 6-OHDA-induced model of Parkinson's disease. J. Neurochem. 2009, 109, 879-888. [CrossRef] [PubMed]

46. Sharma, P.; Ahmad-Shah, Z.; Kumar, A.; Islam, F.; Mishra, K.P. Role of combined administration of Tiron and glutathione against aluminum-induced oxidative stress in rat brain. J. Trace Elem. Med. Biol. 2007, 21, 63-70. [CrossRef] [PubMed]

47. Moumen, R.; Ait-Oukhata, N.; Bureau, F.; Fleury, C.; Bougle, D.; Arhan, P. Aluminium increases xanthine oxidase activity and disturbs antioxidant status in the rat. J. Trace Elem. Med. Biol. 2001, 15, 89-93. [CrossRef]

48. González-Muñoz, M.J.; Meseguer, I.; Sánchez-Reus, M.I.; Schultz, A.; Olivero, R.; Benedí, J.; Sánchez-Muniz, F.J. Beer consumption reduces cerebral oxidation caused by aluminum toxicity by normalizing gene expression of tumor necrotic factor alpha and several antioxidant enzymes. Food Chem. Toxicol. 2008, 46, 1111-1118. [CrossRef] [PubMed]

49. Tarkowski, E.; Andreasen, N.; Tarkowski, A.; Blennow, K. Intrathecal inflammation precedes development of Alzheimer's disease. J. Neurol. Neurosurg. Psychiatry 2003, 74, 1200-1205. [CrossRef] [PubMed]

50. Becaria, A.; Lahiri, D.K.; Bondy, S.C.; Chen, D.; Hamadeh, A.; Li, H. Aluminium and cooper in drinking water enhance inflammatory or oxidative events specifically in the brain. J. Neuroinmunol. 2006, 176, 16-23. [CrossRef] [PubMed]

51. Lukiw, W.J.; Percy, M.E.; Kruck, T.P. Nanomolar aluminum induces pro-inflammatory and pro-apoptotic gene expression in human brain cells in primary culture. J. Inorg. Biochem. 2005, 99, 1895-1898. [CrossRef]

52. Abdel-Aal, R.A.; Assi, A.A.; Kostandy, B.B. Rivastigmine reverses aluminum-induced behavioral changes in rats. Eur. J. Pharmacol. 2011, 659, 169-176. [CrossRef] 
53. Martinez, C.S.; Escobar, A.G.; Uranga-Ocio, J.A.; Peçanha, F.M.; Vassallo, D.V.; Exley, C.; Miguel, M.; Wiggers, G.A. Aluminium exposure for 60 days at human dietary levels impairs spermatogenesis and sperm quality in rats. Reprod. Toxicol. 2017, 73, 128-141. [CrossRef]

54. Kaizer, R.R.; Correa, M.C.; Spanevello, R.M.; Morsch, V.M.; Mazzanti, C.M.; Gonçalves, J.F.; Schetinger, M.R. Acetylcholinesterase activation and enhanced lipid peroxidation after long-term exposure to low levels of aluminum on different mouse brain regions. J. Inorg. Biochem. 2005, 9, 1865-1870. [CrossRef] [PubMed]

55. Kumar, S. Aluminium-induced biphasic effect. Med. Hypotheses 1999, 52, 557-559. [CrossRef]

56. Solfrizzi, V.; Panza, F.; Torres, F.; Mastroianni, F.; Del Parigi, A.; Venezia, A.; Capurso, A. High monounsaturated fatty acids intake protects against age-related cognitive decline. Neurology 1999, 52, 1563-1569. [CrossRef] [PubMed]

57. Berr, C.; Portet, F.; Carriere, I.; Akbaraly, T.N.; Feart, C.; Gourlet, V.; Combe, N.; Barberger-Gateau, P.; Ritchie, K. Olive oil and cognition: Results from the three-city study. Dement. Geriatr. Cogn. Disord. 2009, 28, 357-364. [CrossRef] [PubMed]

58. Yannakoulia, M.; Kontogianni, M.; Scarmeas, N. Cognitive health and Mediterranean diet: Just diet or lifestyle pattern? Ageing Res. Rev. 2015, 20, 74-78. [CrossRef] [PubMed]

59. Jacka, F.N.; Cherbuin, N.; Anstey, K.J.; Sachdev, P.; Butterworth, P. Western diet is associated with a smaller hippocampus: A longitudinal investigation. BMC Med. 2015, 8, 215. [CrossRef] [PubMed]

60. Gu, Y.; Brickman, A.M.; Stern, Y.; Habeck, C.G.; Razlighi, Q.R.; Luchsinger, J.A.; Manly, J.J.; Schupf, N.; Mayeux, R.; Scarmeas, N. Mediterranean diet and brain structure in a multiethnic elderly cohort. Neurology 2015, 85, 1744-1751. [CrossRef] [PubMed]

61. Matthews, D.C.; Davies, M.; Murray, J.; Williams, S.; Tsui, W.H.; Li, Y.; Andrews, R.D.; Lukic, A.; McHugh, P.; Vallabhajosula, S.; et al. Physical activity, Mediterranean diet and biomarkers-assessed risk of Alzheimer is a multi-modality brain imaging study. Adv. J. Mol. Imaging 2014, 4, 43-57. [CrossRef] [PubMed]

62. Turner, P.L.; Principal, M.A. Circadian photoreception: Aging and the eye's important role in systemic health. Br. J. Ophthalmol. 2008, 92, 1439-1444. [CrossRef] [PubMed]

63. Gesteiro, E.; Sánchez-Muniz, F.J.; Bastida, S. Hypercortisolemia and hyperinsulinemia interaction and their impact upon insulin resistance/sensitivity markers at birth. In Blood Banking for Clinical Application and Regenerative Medicine; Colette-Mauricio, A., Ed.; InTech: Rijeka, Croatia, 2017; pp. 491-503.

64. Del Chierico, F.; Vernocchi, P.; Dallapiccola, B.; Putignani, L. Mediterranean diet and health: Food effects on gut microbiota and disease control. Int. J. Mol. Sci. 2014, 15, 11678-11699. [CrossRef] [PubMed]

65. Trichopoulou, A.; Martínez-González, M.A.; Tong, T.Y.; Forouhi, N.G.; Khandelwal, S.; Prabhakaran, D.; Mozaffarian, D.; de Lorgeril, M. Definitions and potential health benefits of the Mediterranean diet: Views from experts around the world. BMC Med. 2014, 12, 112. [CrossRef] [PubMed]

66. Castro-Quezada, I.; Román-Viñas, B.; Serra-Majem, L. Nutritional adequacy of the Mediterranean diet. In The Mediterranean Diet: An Evidence-Based Approach; Preedy, V.R., Ross-Watson, R., Eds.; Academic Press: Amsterdam, The Netherlands, 2015; pp. 13-21.

67. Trichopoulou, A. Traditional Mediterranean diet and longevity in the elderly: A review. Public Health Nutr. 2004, 7, 943-947. [CrossRef] [PubMed]

68. Vasto, S.; Buscemi, S.; Barera, A.; Di Carlo, M.; Accardi, G.; Caruso, C. Mediterranean diet and healthy ageing: A Sicilian perspective. Gerontology 2014, 60, 508-518. [CrossRef] [PubMed]

69. Vasto, S.; Barera, A.; Rizzo, C.; Di Carlo, M.; Caruso, C.; Panotopoulos, G. Mediterranean diet and longevity: An example of nutraceuticals? Curr. Vasc. Pharmacol. 2014, 12, 735-738. [CrossRef] [PubMed]

70. Keys, A.; Menotti, A.; Karvonen, M.J.; Aravanis, C.; Blackburn, H.; Buzina, R. The diet and 15-years dea Beer Drinking Associates with Lower Burden of Amyloid Beta Aggregation in the Brain: Helsinki Sudden Death Series. Alcohol. Clin. Exp. Res. 1986, 40, 1473-1478.

71. Ruiz-Liso, J.M.; Ruiz-García, J. Temple of health based on the Mediterranean diet. J. Neg. Non Pos. Res. 2019, 4, 492-506.

72. González-Gross, M.; Gómez-Llorente, J.J.; Valtueña, J.; Ortiz, J.C.; Meléndez, A. La "pirámide de la guía de estilo de vida saludable" para niños y adolescentes. Nutr. Hosp. 2008, 23, 159-168.

73. Aranceta-Bartrina, J.; Arija-Val, V.; Maíz-Aldalur, E.; Martínez de la Victoria-Muñoz, E.; Ortega-Anta, R.M.; Pérez-Rodrigo, C.; Quiles-Izquierdo, J.; Rodríguez-Martín, A.; Román-Viñas, B.; Salvador-Castell, G.; et al. SENC-Dietary Guidelines. Nutr. Hosp. 2016, 33, 1-48. 
74. Sánchez-Muniz, F.J. Aceite de oliva, clave de vida en la Cuenca Mediterránea. Anales de la Real Academia Nacional de Farmacia 2007, 73, 653-692.

75. Bastida, S.; Sánchez-Muniz, F.J. Frying a cultural way of cooking in the Mediterranean diet. In The Mediterranean Diet: An Evidence-Based Approach; Preedy, V.R., Watson, R.R., Eds.; Elsevier: Amsterdam, The Netherlands, 2015; pp. 217-234.

76. Arranz, A.; Chiva-Blanch, G.; Valderas Martínez, P.; Casas, R.; Estruch, R. Beer: Beneficial aspects and contribution to the Mediterranean diet. In The Mediterranean Diet: An Evidence-Based Approach; Preedy, V.R., Ross-Watson, R., Eds.; Academic Press: Amsterdam, The Netherlands, 2015; pp. 153-164.

77. Noah, A.; Truswell, A.S. There are many Mediterranean diets. Asia Pacific J. Clin. Nutr. 2001, 10, 2-9. [CrossRef]

78. Davis, C.; Bryan, J.; Hodgson, J.; Murphy, K. Definition of the Mediterranean Diet: A Literature Review. Nutrients 2015, 7, 9139-9153. [CrossRef] [PubMed]

79. Kirin Holding Company. Global Beer Consumption by Country in 2016. 2017. Available online: www. kirinholdings.co.jp/english/news/2017/1221_01.html (accessed on 1 May 2019).

80. Otaegui-Arrazola, A.; Amiano, P.; Elbusto, A.; Urdaneta, E.; Martínez-Lage, P. Diet, cognition, and Alzheimer's disease: Food for thought. Eur. J. Nutr. 2014, 53, 1-23. [CrossRef] [PubMed]

81. Lourida, I.; Soni, M.; Thompson-Coon, J.; Purandare, N.; Lang, I.A.; Ukoumunne, O.C.; Llewellyn, D.J. Mediterranean diet, cognitive function, and dementia: A systematic review. Epidemiology 2013, 24, 479-489. [CrossRef] [PubMed]

82. Psaltopoulou, T.; Sergentanis, T.N.; Panagiotakos, D.B.; Sergentanis, I.N.; Kosti, R.; Scarmeas, N. Mediterranean diet, stroke, cognitive impairment, and depression: A meta-analysis. Ann. Neurol. 2013, 74, 580-591. [CrossRef] [PubMed]

83. Singh, B.; Parsaik, A.K.; Mielke, M.M. Association of Mediterranean diet with mild cognitive impairment and Alzheimer's disease: A systematic review and meta-analysis. J. Alzheimers Dis. 2014, 39, 271-282. [CrossRef] [PubMed]

84. Macpherson, H.; Lee, J.; Villalon, L.; Pase, M.; Pipingas, A.; Scholey, A. The influence of Mediterranean diet on cognitive health. In The Mediterranean Diet. An Evidence-Based Approach; Preedy, V., Watson, R.R., Eds.; Academic Press: Amsterdam, The Netherlands, 2015; pp. 81-88.

85. Samieri, C.; Okereke, O.I.; Devore, E.; Grodstein, F. Long-term adherence to the Mediterranean diet is associated with overall cognitive status, but not cognitive decline, in women. J. Nutr. 2013, 143, 493-499. [CrossRef] [PubMed]

86. Titova, O.E.; Ax, E.; Brooks, S.J.; Sjögren, P.; Cederholm, T.; Kilander, L.; Kullberg, J.; Larsson, E.M.; Johansson, L.; Ahlström, H.; et al. Mediterranean diet habits in older individuals: Associations with cognitive functioning and brain volumes. Exp. Gerontol. 2013, 48, 1443-1448. [CrossRef] [PubMed]

87. Martínez-Lapiscina, E.H.; Clavero, P.; Toledo, E.; Estruch, R.; Salas-Salvadó, J.; San Julián, B.; Sanchez-Tainta, A.; Ros, E.; Valls-Pedret, C.; Martinez-Gonzalez, M.Á. Mediterranean diet improves cognition: The PREDIMED-NAVARRA randomised trial. J. Neurol. Neurosurg. Psychiatry 2013, 84, 1318-1325. [CrossRef] [PubMed]

88. Arranz, S.; Chiva-Blanch, G.; Valderas Martínez, P.; Medina-Remón, A.; Lamuela-Raventós, R.M.; Estruch, R. Wine, beer, alcohol and polyphenols on cardiovascular disease and cancer. Nutrients 2012, 4, $759-781$. [CrossRef] [PubMed]

89. Chiva-Blanch, G.; Magraner, E.; Condines, X.; Valderas-Martínez, P.; Roth, I.; Arranz, S.; Casas, R.; Navarro, M.; Hervas, A.; Sisó, A.; et al. Effects of alcohol and polyphenols from beer on atherosclerotic biomarkers in high cardiovascular risk men: A randomized feeding trial. Nutr. Metab. Cardiovasc. Dis. 2015, 25, 36-45. [CrossRef] [PubMed]

90. Anastasiou, C.A.; Yannakoulia, M.; Kosmidis, M.H.; Dardiotis, E.; Hadjigeorgiou, G.M.; Sakka, P.; Arampatzi, X.; Bougea, A.; Labropoulos, I.; Scarmeas, N. Mediterranean diet and cognitive health: Initial results from the Hellenic Longitudinal Investigation of Ageing and Diet. PLoS ONE 2017, 12, e0182048. [CrossRef] [PubMed] 
91. Gorelick, P.B.; Scuteri, A.; Black, S.E. American Heart Association Stroke Council, Council on Epidemiology and Prevention, Councilon Cardiovascular Nursing, Council on Cardiovascular Radiology and Intervention, and Council on Cardiovascular Surgery and Anesthesia. Vascular contributions to cognitive impairment and dementia: A statement for health care professionals from the American heart association/american stroke association. Stroke 2011, 42, 2672-2713. [PubMed]

92. Loy, C.T.; Twigg, S.M. Growth factors, AGEing, and the diabetes link in Alzheimer's disease. J. Alzheimers Dis. 2009, 16, 823-831. [CrossRef] [PubMed]

93. Smith, P.J.; Blumenthal, J.A.; Hoffman, B.M.; Cooper, H.; Strauman, T.A.; Welsh-Bohmer, K.; Browndyke, J.N.; Sherwood, A. Aerobic exercise and neurocognitive performance: A meta-analytic review of randomized controlled trials. Psychosom. Med. 2010, 72, 239-252. [CrossRef] [PubMed]

94. Valls-Pedret, C.; Sala-Vila, A.; Serra-Mir, M.; Corella, D.; de la Torre, R.; Martínez-González, M.Á.; Martínez-Lapiscina, E.H.; Fitó, M.; Pérez-Heras, A.; Salas-Salvadó, J.; et al. Mediterranean diet and age-related cognitive decline: A randomized clinical trial. JAMA Intern. Med. 2015, 175, 1094-1103. [CrossRef] [PubMed]

95. Scarmeas, N.; Stern, Y.; Mayeux, R.; Manly, J.J.; Schupf, N.; Luchsinger, J.A. Mediterranean diet and mild cognitive impairment. Arch. Neurol. 2009, 66, 216-225. [CrossRef] [PubMed]

96. Gardener, S.; Gu, Y.; Rainey-Smith, S.R.; Keogh, J.B.; Clifton, P.M.; Mathieson, S.L.; Taddei, K.; Mondal, A.; Ward, V.K.; Scarmeas, N.; et al. Adherence to a Mediterranean diet and Alzheimer's disease risk in an Australian population. Transl. Psychiatry 2012, 2, e164. [CrossRef] [PubMed]

97. Pitsavos, C.; Panagiotakos, D.B.; Tzima, N.; Chrysohoou, C.; Economou, M.; Zampelas, A.; Stefanadis, C. Adherence to the Mediterranean diet is associated with total antioxidant capacity in healthy adults: The ATTICA study. Am. J. Clin. Nutr. 2005, 82, 694-699. [CrossRef]

98. Salas-Salvadó, J.; Garcia-Arellano, A.; Estruch, R.; Marquez-Sandoval, F.; Corella, D.; Fiol, M.; Gómez-Gracia, E.; Viñoles, E.; Arós, F.; Herrera, C.; et al. Components of the Mediterranean-type food pattern and serum inflammatory markers among patients at high risk for cardiovascular disease. Eur. J. Clin. Nutr. 2008, 62, 651-659. [CrossRef]

99. Von Bernhardi, R.; Eugenín, J. Alzheimer's disease: Redox dysregulation as a common denominator for diverse pathogenic mechanisms. Antioxid. Redox Signal. 2012, 16, 974-1031. [CrossRef]

100. Sastre, M.; Klockgether, T.; Heneka, M.T. Contribution of inflammatory processes to Alzheimer's disease: Molecular mechanisms. Int. J. Dev. Neurosci. 2006, 24, 167-176. [CrossRef] [PubMed]

101. Abuznait, A.H.; Qosa, H.; Busnena, B.A.; ElSayed, K.A.; Kaddoumi, A. Olive-oil-derived oleocanthal enhances $\beta$-amyloid clearance as a potential neuroprotective mechanism against Alzheimer's disease: In vitro and in vivo studies. ACS Chem. Neurosci. 2013, 4, 973-982. [CrossRef] [PubMed]

102. Bulló, M.; Lamuela-Raventós, R.; Salas-Salvadó, J. Mediterranean diet and oxidation: Nuts and olive oil as important sources of fat and antioxidants. Curr. Top. Med. Chem. 2011, 11, 1797-1810. [CrossRef] [PubMed]

103. Del Rio, D.; Rodriguez-Mateos, A.; Spencer, J.P.; Tognolini, M.; Borges, G.; Crozier, A. Dietary (poly) phenolics in human health: Structures, bioavailability, and evidence of protective effects against chronic diseases. Antiox. Redox Signal. 2013, 18, 1818-1892. [CrossRef] [PubMed]

104. Solfrizzi, V.; Panza, F.; Frisardi, V.; Seripa, D.; Logroscino, G.; Imbimbo, B.P.; Pilotto, A. Diet and Alzheimer's disease risk factors or prevention: The current evidence. Expert Rev. Neurother. 2011, 11, 677-708. [CrossRef] [PubMed]

105. Escamilla-Hurtado, M.L.; Escamilla-Hurtado, M.G. Los alimentos fermentados que consumían nuestros bisabuelos prehispánicos. Ciencia 2007, 58, 75-84.

106. Nelson, M. The Barbarian's Beverage: A History of Beer in Ancient Europe; Routledge: London, UK, 2005.

107. Beer Composition and Nutritional Elements. Data from the National Nutrient Database for Standard Reference (USDA). Available online: https://ndb.nal.usda.gov/ndb/search/list (accessed on 1 May 2019).

108. Ares-Peón, I.A.; Garrote, G.; Domínguez, H.; Parajó, J.C. Phenolics production from alkaline hydrolysis of autohydrolysis liquors. CyTA J. Food 2016, 14, 255-265. [CrossRef]

109. Porretta, S.; Donadini, G. A Preference Study for No Alcohol Beer in Italy Using Quantitative Concept Analysis. J. Inst. Brew. 2008, 114, 315-321. [CrossRef]

110. INSERM Collective Expertise Centre. Alcohol: Social Damages, Abuse, and Dependence. Institut National de la Santé et de la Recherche Médicale, 2003. Available online: https://www.ncbi.nlm.nih.gov/books/NBK10785/ (accessed on 30 May 2019). 
111. Kok, E.H.; Karppinen, T.T.; Luoto, T.; Alafuzoff, I.; Karhunen, P.J. Beer Drinking Associates with Lower Burden of Amyloid Beta Aggregation in the Brain: Helsinki Sudden Death Series. Alcohol Clin. Exp Res. 2016, 40, 1473-1478. [CrossRef]

112. Collins, M.A.; Neafsey, E.J.; Mukamal, K.J.; Gray, M.O.; Parks, D.A.; Das, D.K.; Korthuis, R.J. Alcohol in moderation, cardioprotection, and neuroprotection: Epidemiological considerations and mechanistic studies. Alcohol Clin. Exp. Res. 2009, 33, 206-219. [CrossRef]

113. Downer, B.; Jiang, Y.; Zanjani, F.; Fardo, D. Effects of alcohol consumption on cognition and regional brain volumes among older adults. Am. J. Alzheimers Dis. Other Demen. 2015, 30, 364-374. [CrossRef] [PubMed]

114. Heymann, D.; Stern, Y.; Cosentino, S.; Tatarina-Nulman, O.; N Dorrejo, J.; Gu, Y. The association between alcohol use and the progression of Alzheimer's disease. Curr. Alzheimers Res. 2016, 13, 1356-1362. [CrossRef]

115. Mukamal, K.J.; Kuller, L.H.; Fitzpatrick, A.L.; Longstreth-Jr, W.T.; Mittleman, M.A.; Siscovick, D.S. Prospective study of alcohol consumption and risk of dementia in older adults. JAMA 2003, 289, 1405-1413. [CrossRef] [PubMed]

116. Luchsinger, J.A.; Tang, M.X.; Siddiqui, M.; Shea, S.; Mayeux, R. Alcohol intake and risk of dementia. J. Am. Geriatrics Soc. 2004, 52, 540-546. [CrossRef] [PubMed]

117. Winkler, C.; Wirleitner, B.; Schroecksnadel, K.; Schennach, H.; Fuchs, D. Beer down-regulates activated peripheral blood mononuclear cells in vitro. Int. Immunopharmacol. 2006, 6, 390-395. [CrossRef] [PubMed]

118. Polak, J.; Bartoszek, M.; Stanimirova, I. A study of the antioxidant properties of beers using electron paramagnetic resonance. Food Chem. 2013, 14, 3042-3049. [CrossRef] [PubMed]

119. Sripanyakorn, S.; Jugdaohsingh, R.; Elliott, H.; Walker, C.; Mehta, P.; Shoukru, S. The silicon content of beer and its bioavailability in healthy volunteers. Brit. J. Nutr. 2004, 91, 403-409. [CrossRef]

120. Peña, A.; Meseguer, I.; González-Muñoz, M.J. Influencia del consumo moderado de cerveza sobre la toxicocinética del aluminio: Estudio agudo. Nutr. Hosp. 2007, 22, 371-376.

121. Granero, S.; Vicente, M.; Aguilar, V.; Martínez-Para, M.C.; Domingo, J.L. Effects of beer as a source of dietary silicon on aluminum absorption and retention in mice. Trace Elem. Electrol. 2004, 21, 28-32. [CrossRef]

122. González-Muñoz, M.J.; Peña, A.; Meseguer, M.I. Role of beer as a possible protective factor in preventing Alzheimer's disease. Food Chem. Toxicol. 2008, 46, 49-56. [CrossRef]

123. Merino, P.; Santos-López, J.A.; Mateos, C.; Meseguer, I.; Garcimartín, A.; Bastida, S.; Sánchez-Muniz, F.J.; Benedí, J.; González-Muñoz, M.J. Can nonalcoholic beer, silicon and hops reduce the brain damage and behavioral changes induced by aluminum nitrate in young male Wistar rats? Food Chem. Toxicol. 2018, 118, 784-794. [CrossRef] [PubMed]

124. Sasaoka, N.; Sakamoto, M.; Kanemori, S.; Kan, M.; Tsukano, C.; Takemoto, Y.; Kakizuka, A. Long-term oral administration of hop flower extracts mitigates Alzheimer phenotypes in mice. PLoS ONE 2014, 9, e87185. [CrossRef] [PubMed]

125. Callemien, D.; Jerkovic, V.; Rozenberg, R.; Collin, S. Hop as an interesting source of resveratrol for brewers: Optimization of the extraction and quantitative study by liquid chromatography/atmospheric pressure chemical ionization tandem mass spectrometry. J. Agric. Food Chem. 2005, 53, 424-429. [CrossRef] [PubMed]

126. Gillette-Guyonnet, S.; Andrieu, S.; Nourhashemi, F.; de la Gueronniere, V.; Grandjean, H.; Vellas, B. Cognitive impairment and composition of drinking water in women: Finding of the EPIDOS study. Am. J. Clin. Nutr. 2005, 81, 897-902. [CrossRef] [PubMed]

127. Gillette-Guyonnet, S.; Andrieu, S.; Vellas, B. The potential influence of silica presents in drinking water on Alzheimer's disease and associated disorders. J. Nutr. Health Aging 2007, 11, 119-124. [PubMed]

128. Garcimartín, A.; Merino, J.J.; Santos-López, J.A.; López-Oliva, M.E.; González, M.P.; Sánchez-Muniz, F.J.; Benedí, J. Silicon as neuroprotector or neurotoxic in the human neuroblastoma SH-SY5Y cell line. Chemosphere 2015, 135, 217-224. [CrossRef] [PubMed]

129. Maldonado, M.D.; Moreno, H.; Calvo, J.R. Melatonin present in beer contributes to increase the levels of melatonin and antioxidant capacity of the human serum. Clin. Nutr. 2009, 28, 188-191. [CrossRef] [PubMed]

130. Rosales-Corral, S.A.; Acuña-Castroviejo, D.; Coto-Montes, A.; Boga, J.A.; Manchester, L.C.; Fuentes-Broto, L.; Reiter, R.J. Alzheimer's disease: Pathological mechanisms and the beneficial role of melatonin. J. Pineal Res. 2012, 52, 167-202. [CrossRef] [PubMed]

131. Matsubara, E.; Bryant-Thomas, T.; Pacheco Quinto, J.; Henry, T.L.; Poeggeler, B.; Herbert, D.; Shoji, M. Melatonin increases survival and inhibits oxidative and amyloid pathology in a transgenic model of Alzheimer's disease. J. Neurochem. 2003, 85, 1101-1108. [CrossRef] [PubMed] 
132. Masilamoni, J.G.; Jesudason, E.P.; Dhandayuthapani, S.; Ashok, B.S.; Vignesh, S.; Jebaraj, W.C.; Paul, S.F.; Jayakumar, R. The neuroprotective role of melatonin against amyloid beta peptide injected mice. Free Radic. Res. 2008, 42, 661-673. [CrossRef]

133. Hornedo-Ortega, R.; Cerezo, A.B.; Troncoso, A.M.; Garcia-Parrilla, M.C.; Mas, A. Melatonin and other tryptophan metabolites produced by yeasts: Implications in cardiovascular and neurodegenerative diseases. Front. Microbiol. 2016, 6, 1565. [CrossRef]

134. Szwajgier, D. Anticholinesterase activity of phenolic acids and their derivatives. Zeitschrift für Naturforschung C 2013, 68, 125-132. [CrossRef]

135. Szwajgier, D.; Borowiec, K. Phenolic acids from malt are efficient acetylcholinesterase and butyrylcholinesterase inhibitors. J. Inst. Brew. 2012, 118, 40-48. [CrossRef]

136. Hamaguchi, T.; Ono, K.; Murase, A.; Yamada, M. Phenolic compounds prevent Alzheimer's pathology through different effects on the amyloid- $\beta$ aggregation pathway. Am. J. Patol. 2009, 175, 2557-2565. [CrossRef] [PubMed]

137. Huang, X.; Wang, J.; Chen, X.; Liu, P.; Wang, S.; Song, F.; Zhang, Z.; Zhu, F.; Huang, X.; Liu, J.; et al. The prenylflavonoid xanthohumol reduces Alzheimer-like changes and modulates multiple pathogenic molecular pathways in the neuro2a/APPswe cell model of AD. Front. Pharmacol. 2018, 9, 199. [CrossRef] [PubMed]

138. Ano, Y.; Dohata, A.; Taniguchi, Y.; Hoshi, A.; Uchida, K.; Takashima, A.; Nakayama, H. Iso- $\alpha$-acids, bitter components of beer, prevent inflammation and cognitive decline induced in a mouse model of Alzheimer's disease. J. Biol. Chem. 2017, 292, 3720-3728. [CrossRef] [PubMed]

139. Ano, Y.; Hoshi, A.; Ayabe, T.; Takashima, A.; Nakayama, H. Iso- $\alpha$-acids, bitter components in beer, improve hippocampus-dependent memory via dopamine release. Alzheimers Demen. J Alzheimer Assoc. 2018, 14, 304. [CrossRef]

140. Ano, Y.; Yoshikawa, M.; Takaichi, Y.; Michikawa, M.; Uchida, K.; Nakayama, H.; Takashima, A. Iso- $\alpha$-Acids, bitter components in beer, suppress inflammatory responses and attenuate neural hyperactivation in the hippocampus. Front. Pharmacol. 2019, 10, 81. [CrossRef]

141. Fukuda, T.; Uchida, K.; Nakayama, H.; Ano, Y. Short-term administration of iso- $\alpha$-acids increases transthyretin transcription in the hippocampus. Biochem. Biophys. Res. Commun. 2018, 507, 471-475. [CrossRef] [PubMed]

142. Ayabe, T.; Ohya, R.; Ano, Y. Hop-Derived Iso- $\alpha$-Acids in Beer Improve Visual Discrimination and Reversal Learning in Mice as Assessed by a Touch Panel Operant System. Front. Behav. Neurosci. 2019, $13,67$. [CrossRef] [PubMed]

143. Taylor, A.W.; Barofsky, E.; Kennedy, J.A.; Deinzer, M.L. Hop (Humulus lupulus L.) proanthocyanidins characterized by mass spectrometry, acid catalysis, and gel permeation chromatography. J. Agric. Food Chem. 2003, 51, 4101-4110. [CrossRef] [PubMed]

144. De Keukeleire, D.; De Cooman, L.; Rong, H.; Heyerick, A.; Kalita, J.; Milligan, S.R. Functional properties of hop polyphenols. Basic Life Sci. 1999, 66, 739-760. [PubMed]

145. Nikolic, D.; Li, Y.; Chadwick, L.R.; Grubjesic, S.; Schwab, P.; Metz, P.; van Breemen, R.B. Metabolism of 8-prenylnaringenin, a potent phytoestrogen from hops (Humulus lupulus), by human liver microsomes. Drug Metab. Dispos. 2004, 32, 272-279. [CrossRef] [PubMed]

146. Dong, L.; Hou, Y.; Li, F.; Piao, Y.; Zhang, X.; Zhang, X.; Li, C.; Zhao, C. Characterization of volatile aroma compounds in different brewing barley cultivars. J. Sci. Food Agric. 2015, 95, 915-921. [CrossRef] [PubMed]

147. Van Cleemput, M.; Heyerick, A.; Libert, C.; Swerts, K.; Philippé, J.; De Keukeleire, D.; Haegeman, G.; De Bosscher, K. Hop bitter acids efficiently block inflammation independent of GRalpha, PPARalpha, or PPARgamma. Mol. Nutr. Food Res. 2009, 53, 1143-1155. [CrossRef]

148. Rancán, L.; Paredes, S.D.; García, I.; Muñoz, P.; García, C.; López de Hontanar, G.; de la Fuente, M.; Vara, E.; Tresguerres, J.A.F. Protective effect of xanthohumol against age-related brain damage. J. Nutr. Biochem. 2017, 49, 133-140. [CrossRef]

149. Chumlea, W.C. Editorial: Silica, a mineral of unknown but emerging health importance. J. Nutr. Health Aging 2007, 11, 93.

150. Santos-López, J.A.; Garcimartín, A.; Merino, P.; López-Oliva, M.E.; Bastida, S.; Benedí, J.; Sánchez-Muniz, F.J. Effects of silicon vs. hydroxytyrosol-enriched restructured pork on liver oxidation status of aged rats fed high-Saturated/high-Cholesterol Diet. PLoS ONE 2016, 11, e0147469. [CrossRef] 
151. Wu, Z.H.; Du, Y.M.; Xue, H.; Wu, Y.; Zhou, B. Aluminium induces neurodegeneration and its toxicity arises from increased iron accumulation and reactive oxygen species (ROS) production. Neurobiol. Aging 2012, 33, e1-e199. [CrossRef]

152. Parry, R.; Plowman, D.; Trevor Delves, H.; Roberts, N.B.; Birchall, J.D.; Bellia, J.P. Silicon and aluminum interactions in haemodialysis patients. Nephrol. Dial. Transp. 1998, 13, 1759-1762. [CrossRef]

153. Reffitt, D.M.; Jugdaohsingh, R.; Thompson, R.P.; Powell, J.J.; Hampson, G.N. Silicic acid: Its gastrointestinal uptake and urinary excretion in men and effects on aluminum excretion. Inorganic Biochem. 1999, 76, 141-147. [CrossRef]

154. Birchall, J.D.; Chappell, J.S. Aluminium, water chemistry, and Alzheimer's disease. Lancet 1989, $29,953$. [CrossRef]

155. Martin, K.R. Silicon: The health benefits of a metalloid. Met Ions Life Sci. 2013, 13, 451-473. [PubMed]

156. Vargas, C.R.; Wajner, M.; Sirtori, L.R.; Goulart, L.; Chiochetta, M.; Coelho, D. Evidence that oxidative stress is increased in patients with X-linked adrenoleukodystrophy. Biochem. Biophys. Acta 2004, 1688, $26-32$. [CrossRef] [PubMed]

157. Gómez, M.; Esperza, J.L.; Nogués, M.R.; Giralt, M.; Cabré, M.; Domingo, J.L. Pro-oxidant activity of aluminum in the rat hippocampus: Gene expression of antioxidant enzymes alters melatonin administration. Free Rad. Biol. Med. 2005, 38, 104-111. [CrossRef] [PubMed]

158. Srivastava, R.A.; Jain, J.C. Scavenger receptor class B type I expression and elemental analysis in cerebellum and parietal cortex regions of the Alzheimer's disease brain. J. Neurol. Sci. 2002, 196, 45-52. [CrossRef]

159. Valls-Belles, V.; Codoner-Franch, P.; Villarino Marin, A.; Martinez-Alvarez, J.R. Effect of hop supplementation in oxidative metabolism and inflammation parameters. In Proceedings of the Functional Foods in Europe: International Developments in Science and Health Claims: Summary Report of an International Symposium, Portomaso, Malta, 9-11 May 2007; p. 45.

160. Thambyrajah, J.; Townend, J.N. Homocysteine and atherothrombosis mechanism for injury. Eur. Heart J. 2000, 21, 967-974. [CrossRef] [PubMed]

161. Ravaglia, G.; Forti, P.; Maioli, F.; Muscari, A.; Scchetti, L. Homocysteine and cognitive function in healthy elderly community dwellers in Italy. Am. J. Clin. Nutr. 2003, 77, 668-673. [CrossRef] [PubMed]

162. Whitmer, R.A.; Haan, M.N.; Miller, J.W.; Yaffe, K. Hormone replacement therapy and cognitive performance: The role of homocysteine. J. Gerontol. Biol. Sci. Med. Sci. 2003, 58, 324-330. [CrossRef]

163. Reiter, R.J.; Tan, D.X.; Maldonado, M.D. Melatonin as an antioxidant: Physiology versus pharmacology. J. Pineal Res. 2005, 39, 215-216. [CrossRef]

164. Bieschke, J.; Zhang, Q.; Powers, E.T.; Lerner, R.A.; Kelly, J.W. Oxidative metabolites accelerate Alzheimer's amyloidogenesis by a two-step mechanism, eliminating the requirement for nucleation. Biochemistry 2005, 44, 4977-4983. [CrossRef] [PubMed]

165. Walton, R.J. Chronic aluminum intake causes Alzheimer's disease: Applied Sir Austin Bradford Hill's causality criteria. J. Alzheimers Dis. 2014, 40, 765-838. [CrossRef] [PubMed]

166. Gordillo Bastidas, D.; Gordillo Bastidas, E. (Eds.) Metabolismo del alcohol. In Nutrición Molecular; McGraw Hill Education: Mexico City, Mexico, 2015; pp. 179-188.

167. Casarrubea, M.; Sorbera, F.; Crescimanno, G. Structure of rat behavior in hole-board: I) multivariate analysis of response to anxiety. Physiol. Behav. 2009, 96, 174-179. [CrossRef] [PubMed]

168. Espejo, E.F.; Mir, D. Structure of the rat's behaviour in the hot plate test. Behav. Brain Res. 1993, 56, $171-176$. [CrossRef]

169. Platt, B.; Fiddler, G.; Riedel, G.; Henderson, Z. Toxicidad por aluminio en el cerebro de rata: Pruebas histoquímicas e inmunocitoquímicas. Brain Res. Bull. 2001, 55, 257-267. [CrossRef]

170. Jacqmin-Gadda, H.; Commenges, D.; Letenneur, L.; Dartigues, J.F. Silica and aluminum in drinking water and cognitive impairment in the elderly. Epidemiology 1996, 7, 281-285. [CrossRef] [PubMed]

171. Ogasawara, Y.; Ohata, E.; Sakamoto, T.; Ishii, K.; Takahashi, H.; Tanabe, S. A model of aluminum exposure associated with lipid peroxidation in rat brain. Biol. Trace Elem. Res. 2003, 96, 91-201. [CrossRef]

172. Lang, U.E.; Beglinger, C.; Schweinfurth, N.; Walter, M.; Borgwardt, S. Nutritional aspects of depression. Cell Physiol. Biochem. 2015, 37, 1029-1043. [CrossRef] 
173. Gordillo-Bastidas, E.; Panduro, A.; Gordillo-Bastidas, D.; Zepeda-Carrillo, E.A.; García-Bañuelos, J.J.; Muñoz-Valle, J.F.; Bastidas-Ramírez, B.E. Polymorphisms of alcohol metabolizing enzymes in indigenous Mexican population: Unusual high frequency of CYP2E1*c2 allele. Alcohol Clin. Exp. Res. 2010, 34, 142-149. [CrossRef]

174. Fraga Elenes, R.A.; Hagelsieb Pizano, O. Enfermedad de Alzheimer: Impacto de los ácidos grasos. In Nutrición Molecular; Gordillo Bastidas, D., Gordillo Bastidas, E., Eds.; McGraw Hill Education: Mexico City, Mexico, 2015; pp. 293-306.

175. Zou, F.; Chai, H.S.; Younkin, C.S.; Allen, M.; Crook, J.; Pankratz, V.S.; Carrasquillo, M.M.; Rowley, C.N.; Nair, A.A.; Middha, S.; et al. Brain expression genome-wide association study (eGWAS) identifies human disease-associated variants. PLoS Genet. 2012, 8, e1002707. [CrossRef]

176. Li, Z.; Zhu, H.; Zhang, L.; Qin, C. The intestinal microbiome and Alzheimer's disease: A review. Animal Model Exp. Med. 2018, 1, 180-188. [CrossRef] [PubMed]

177. Jiang, C.; Li, G.; Huang, P.; Liu, Z.; Zhao, B. The Gut Microbiota and Alzheimer's Disease. J. Alzheimers Dis. 2017, 58, 1-15. [CrossRef] [PubMed]

178. Gómez-Eguilaz, M.; Ramon-Trapero, J.L.; Perez-Martinez, L.; Blanco, J.R. The microbiota-gut-brain axis and its great projections. Rev. Neurol. 2019, 68, 111-117. [PubMed]

(C) 2019 by the authors. Licensee MDPI, Basel, Switzerland. This article is an open access article distributed under the terms and conditions of the Creative Commons Attribution (CC BY) license (http://creativecommons.org/licenses/by/4.0/). 